\title{
Debt Overhang and Barter in Russia
}

By : Sergei Guriev, Igor Makarov and Mathilde Maurel

Working Paper Number 339

September 2000 


\title{
DEBT OVERHANG AND BARTER IN RUSSIA
}

\author{
Preliminary version, September 2000 \\ Sergei Guriev, Igor Makarov ${ }^{3}$ and Mathilde Maurel ${ }^{\natural}$
}

\begin{abstract}
In this paper we study, both theoretically and empirically, the relationship between barter and the indebtedness of Russian firms. We build a model in which a firm uses barter to protect its working capital against outside creditors even when barter involves high transaction costs. The main innovation of our work is to allow renegotiation between the firm and its creditors. If the creditors are rational, they often agree to postpone debt payments in order to avoid destroying the firm's working capital. It turns out, however, that even if the firm cannot ensure it will not divert cash ex post, the outcome of renegotiation still provides ex ante incentives to use barter. We show that the greater the debt overhang, the more likely the use of barter, and although the possibility of debt restructuring reduces barter, it does not eliminate it altogether. We also discuss the role of the government bond market and weak bankruptcy legislation. The firm-level evidence is consistent with the model's predictions.
\end{abstract}

Keywords: Barter, demonetisation, debt overhang, renegotiations

\footnotetext{
${ }^{1}$ We are grateful to Sergei Aukutsionek, David Brown and Serguei Tsoukhlo for providing us with data. Part of this work was carried out in the New Economic School's Research Center within the GET project 'Corporate Governance in Russia'. We would like to thank the Ford Foundation and TACIS-ACE Grant 95-4152-R for financial support. We would also like to thank David Brown and Barry Ickes, our colleagues at NES, RECEP as well as the ROSES and participants of the Annual WDI-CEPR Conference on Transition Economics and the NES GET workshop for their helpful comments.

${ }^{2}$ New Economic School, CEPR and WDI. Email : sguriev@nes.ru

${ }^{3}$ Sloan School of Management, M.I.T. Email : imakarov@mit.edu

${ }^{4}$ ROSES-CNRS, CEPR. Email : maurelm@univ-paris1.fr
} 


\section{Introduction}

The extent of demonetisation of Russia's transition economy is striking. According to the Russian Economic Barometer, in 1998 about 55\% of inter-firm transactions were made through barter, while the 1998 Institute for the Economy in Transition survey reports a share of $40 \%$ (with another $10 \%$ carried out in vecksels). There are a number of competing theories offering explanations of the spread of barter in Russia. The most common explanation is the liquidity squeeze. Commander and Mummsen (1998) report that most managers believe the lack of liquidity to be the major cause of barter. The other main explanation is that nonmonetary transactions are a strategic choice made by managers. Karpov (1997) and Gaddy and Ickes (1998) suggest that barter may be used by managers to hide revenues from outside owners and creditors (including the tax authorities) and delay restructuring. In this paper we will try to reconcile both views in a single model.

These two theories (lack of liquidity and the delay in restructuring) are based on very different assumptions and suggest rather different policy implications. The liquidity hypothesis is based on the idea that there is no conflict of interest between managers and investors. The managers choose the strategies that are best for the firm. Barter is involuntary: there is no way of selling for cash since most of the firm's customers do not have any. The managers simply react to the temporary liquidity problems. Therefore, if we assume that the lack of liquidity is the cause of barter, in order to reduce barter it is necessary to loosen monetary policy and make sure that more credit is injected into firms.

On the other hand, the model underlining the role of the lack of restructuring assumes that outside investors have little control over managers and cannot make sure that value-enhancing restructuring is underfaken. Therefore this theory suggests that barter is a result of poor corporate governance and until the protection of investors' rights is improved, lending to such firms will not help to reduce barter. Managers will continue to divert cash for personal consumption (e.g. through offshore firms). Once the cash is taken out of the real sector, the firms' liquidity constraints are not relaxed, so there is no change in real output. On the other hand, the increased consumer demand results in inflation. Hence, the question of whether barter should be explained by temporary liquidity shocks or by the strategic behaviour of managers is not of purely academic interest but has important policy implications, too.

Let us try to provide a consistent formulation of each theory. The lack of restructuring theory assumes that non-monetary transactions are less transparent and therefore make transfer pricing and asset stripping easier for the incumbent management. The liquidity hypothesis states that barter is an involuntary response of managers to the lack of cash. If firm A has to pay firm B for goods supplied and firm A currently has no cash, A may offer B payment in kind. Then B will not be able to pay its own supplier $\mathrm{C}$ in cash and will, likewise, have to pay

\footnotetext{
${ }^{5}$ Given the extent of demonetisation, it is little wonder that there are quite a few other theories and explanations. Hendley et al. (1997) refer to poor payment systems and tax evasion, Marin and Schnitzer (1999) and Carlin et al. (2000) provide evidence that barter can help fight disorganisation, Guriev and Kvassov (2000) show that market concentration is an important determinant of barter. Drebentsov and al. (1999) suggest that the main source of non-monetary transactions is the government's subsidies to inefficient firms. In this paper, we will concentrate on the lack of liquidity and the delay in restructuring models, since those are mutually exclusive while the other theories complement one other.

${ }^{6}$ Formally, Russian law provides a rather high degree of investor rights protection. On the other hand, Gelfer, Pistor and Raiser (2000) show that what really influence's a firm's ability to raise external finance is not the legislation in place, but the effectiveness of legal institutions. See Sonin and Zhuravskaya (2000) for discussion of the differences between intended and actual performance of bankruptcy procedures in Russia.
} 
$\mathrm{C}$ in kind. Certainly, this logic raises a number of questions. First, suppose that $\mathrm{A}$ has a cash windfall. Then A may not want to use it to pay B since A know that B will accept barter because $\mathrm{B}$ knows that $\mathrm{C}$ will accept barter etc. Hence, A may well use the cash for its personal consumption (see Kuznetsov (2000) and Yakovlev (1999) for a detailed account from case studies and the evidence in Guriev and Ickes (2000)). The other question that arises is why firms do not borrow cash from banks. The liquidity constraint story implies that the firms are profitable, and there are enough expected future revenues to make repayment possible. However, due to the problem of moral hazard discussed above, there can be no commitment to repayment. Moreover, if B owes money to a bank, B may actually prefer A to pay in kind since the non-monetary transactions are much less transparent for outside creditors. This point is at the heart of the lack of restructuring theory: the liquidity shortage is endogenous, being a consequence of the poor protection of creditors' rights.

Therefore, these two explanations of barter should not be discussed separately: the liquidity shortage is linked to a lack of credit which in turn is related to a lack of investor's control over managers. The goal of our paper is to explore the link between debt and barter in the presence of imperfect institutions. Many authors have suggested that debt overhang is equivalent to a "100\% tax on monetary transactions" (Hendley et al. (1997)) and therefore provides incentives for barter. The manager uses barter to avoid the "tax" that would wipe out the firm's working capital and would therefore result in under-utilisation of capacities. This means that barter is actually good since it makes it possible to sustain an efficient output level. However, the transaction costs of barter (including legal, search, transportation and storage costs) are high. It is therefore clear why the same outcome cannot be achieved without barter, namely, why the creditors would not agree to postpone debt payments. If the firm only suffers from a temporary liquidity shortage but is solvent in the long-term, the creditor should agree to refinance the debt. The firm will then have an incentive to sell for cash, use the cash for purchasing inputs and pay the debt later. We explicitly model the game with renegotiation and show that when debt restructuring occurs, it does reduce the incentive to barter. On the other hand, the threat of cash diversion by the manager may prevent debt restructuring. Anticipating the failure of debt restructuring, the manager would then still prefer barter. This is the most striking and original feature of the model: debt renegotiation is not sufficient to eradicate the barter phenomenon - the risk of cash diversion distorts the creditor's incentive to participate in the renegotiation process.

Our model therefore implies that in the presence of a cash diversion risk (similar to the "transformation risk" introduced in Myers and Rajan (1998)), barter is a serious threat to outside creditors. As in most debt overhang models, we take the initial level of debt as given. On the other hand the results of the model suggest that the rational creditors should avoid lending to Russian firms until contract enforcement is improved. This is fairly consistent with the fact that bank credit is very low in Russia (EBRD (1999)).

Our model adds an interesting dimension to the stock of literature dealing with soft budget

\footnotetext{
${ }^{7}$ Linz and Krueger (1998) or Aukutsionek (1998) interpret barter as a mechanism used to avoid undue bankruptcy when barter is due to liquidity shortage in a context of imperfect financial market conditions and of credit market imperfections.

${ }^{8}$ Formally, our model applies to the relationship with outside creditors. However, it also describes well the interaction with all creditors whose rights are not protected. A good example of this is wage arrears. Workers (creditors) know that if the manager uses the cash for purposes other than payment of wages due, they will not be paid. Therefore they insist the firm pay their wages whenever it has any cash available. To avoid paying off wage arrears, managers use barter. See Earle and Sabirianova (1999) for a comprehensive analysis of wage arrears in Russia.
} 
constraints. As shown in G. Roland and E. Berglöf (1998), the soft budget constraint usually arises because creditors lack the ability to liquidate the indebted firm when it should be liquidated. In our model, where only the ex post situation is considered, the creditors would like to refinance the firm which is productive ex post but the refinancing fails due to a lack of commitment on the manager's side. Thus the manager chooses inefficient barter in order to avoid liquidation.

The empirical section (Section 3) shows that firm-level evidence is consistent with the model's predictions. We use two different data sources : the Russian Economic Barometer over 1995-96 on a quarterly basis, and the Institute for the Economy in Transition survey matched with the Goskomstat dataset for 1996 and 1997. Section 4 concludes and discusses the main policy implications.

\section{The Model}

In this Section, we suggest a simple model that describes the behaviour of a liquidity constrained firm with outside debt. The firm faces the following choice: if it pays off the debt, it will be stripped of working capital and will not be able to purchase inputs for the next round of production. Therefore the firm would rather hide the cash. One way of doing this is to sell by barter that has no value to the outside creditor (and thus cannot be expropriated by the creditor). Even if barter is costly, it makes it possible to postpone debt payments and finance another round of production which may then make it possible to pay off the debt.

This explanation of the link between liquidity constraint and barter is not, however, fully consistent. Indeed, if the firm is efficient and each additional round of production adds value, why would the creditor not voluntarily restructure the debt? Since forgiving/refinancing the debt should lead to an increased utilisation of the firm's efficient capacities, voluntary renegotiation would result in the delaying of debt service. This argument is common in literature concerning financial contracting in developed countries and debt relief in developing economies ${ }^{10}$, so it is not at all clear why it should not apply to a transition economy.

We provide two alternative answers to this puzzle. First, it turns out that even in the presence of renegotiation, the risk of cash diversion by the firm's manager (so called "transformation risk") may cause barter to emerge. Second, if the creditor has access to investment opportunities that the firm does not have, and if these opportunities yield very high returns, as in the case of Russia's government bond bubble, the creditor will not be interested in debt restructuring.

At the core of the model is the lack of effective bankruptcy procedures. Unlike the conventional models of debt (Hart, 1995), we assume that the creditor cannot gain control of the firm's assets if the firm breaches the debt contract. The assets that the creditor can take over if debt payments are not made on time are limited to cash; barter payments cannot be expropriated by the creditor, nor can he replace the manager.

\subsection{The setting}

There are two agents: a firm $\mathrm{F}$ and an outside creditor $\mathrm{C}$. $\mathrm{F}$ owes $\mathrm{C}$ debt $D_{0}>0$. The firm has a unit of output and no cash. The firm may sell the output either for cash or for barter and

\footnotetext{
${ }^{9}$ Hart (1995), Ch. 5.

${ }^{10}$ See for instance Krugman (1988).
} 
use the revenue to purchase inputs. The relative prices in the cash market are better for the firm than those in the barter market: barter transactions involve high legal, transportation and storage costs. On the other hand, cash revenues can be captured by the creditor while barter revenues cannot. Cash revenues are accrued to F's current account which the creditor can easily seize. In-kind payments have no value to the creditor and can only be used as inputs in F's production.

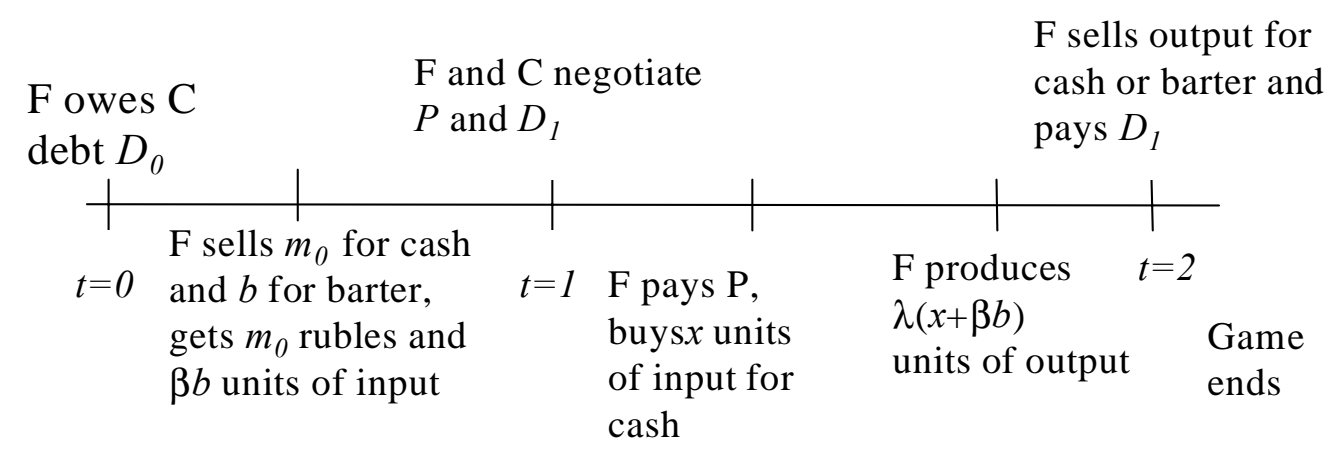

Figure 1. Timing.

There are two periods. 1 The timing is as in Figure 1. At time $t=0, \mathrm{~F}$ has a unit of output and can choose whether to sell it for cash or for barter. The share of output to be sold for cash is $m_{0}$ and the share of output to be sold for barter is $b\left(m_{0}+b \leq 1\right)$. The cash prices of output and input are normalised to 1: selling $m_{0}$ for cash, $\mathrm{F}$ gets $m_{0}$ rubles that can buy $m_{0}$ units of input. The relative barter prices for inputs are $\beta \in[0,1]$ where $(1-\beta)$ represents the transaction costs of barter. Thus, selling $b$ for barter, $\mathrm{F}$ gets $\beta b$ units of input. At time $t=1$, the debt is due. $\mathrm{F}$ and $\mathrm{C}$ observe F's cash revenues and can renegotiate the contract. They bargain over a new contract $\left(P, D_{1}\right)$ where $P$ is the payment at time $t=1$ and $D_{1}$ is the new debt due at $t=2$. If the renegotiation succeeds, F's cash balance becomes $m_{1}=m_{0}-P$, and F promises to pay $D_{1}$ at $t=2$. If the renegotiation fails, $C$ takes $P=\min \left\{m_{0}, D_{0}\right\}$ and invests it elsewhere. ${ }^{1}$ In this case, F onlyhas $m_{1}=m_{0}-\min \left\{m_{0}, D_{0}\right\}=\left[m_{0}-D_{0}\right]_{+}$. The new debt is $D_{1}=D_{0}-\min \left\{m_{0}, D_{0}\right\}=\left[D_{0}-\right.$ $\left.m_{0}\right]_{+}{ }^{1.3}$

After the renegotiations, $\mathrm{F}$ buys inputs for cash. The firm spends $x \in\left[0, m_{1}\right]$ rubles on inputs, so that the total amount of inputs the firm can use for production is $q=\beta b+x$.

\footnotetext{
${ }^{11}$ The two-period setting is chosen to simplify the analysis. Apparently the finite horizon model or infinite horizon model with discounting would produce similar results.

${ }^{12}$ The existing contract gives $\mathrm{C}$ a right to claim $D_{0}$ but $\mathrm{F}$ cannot physically pay more than $m_{0}$ because of the liquidity constraint.

${ }^{13}$ Hereinafter $[\cdot]_{+}$denotes $\max \{\cdot, 0\}$.
} 
The firm has linear technology that converts $q$ units of input into $\lambda q$ units of output. The maximum capacity is one unit of input: $q \leq 1$. Therefore the capacity constraint never binds since $q \leq b+x \leq b+m_{1} \leq b+m_{0} \leq 1$.

Once the output $\lambda q$ is produced, $\mathrm{F}$ decides again whether to sell it for cash or for barter. The cash revenues $m_{2} \in[0, \lambda q]$ can again be confiscated by the creditor if the debt has not yet been repaid. The remaining cash is used for consumption by F's owners. Then the game ends.

The gross interest rate in the economy is normalised to 1 . Therefore the creditor's and the firm's payoffs are respectively:

$U^{C}=P+\min \left\{m_{2}, D_{1}\right\}$

and

$U^{F}=m_{1}-x+\left[m_{2}-D_{1}\right]_{+}$

\subsection{Assumptions}

1. For simplicity's sake we will make a few assumptions concerning the firm's productivity $\lambda$ and transaction costs of barter $1-\beta$ :

$$
1<1 / \beta<\lambda<2
$$

The first inequality implies that barter is less efficient than money: $\beta<1$. The second inequality states that the firm's productivity is high enough to ensure that even with the relative prices $\beta$, the firm adds value: $\lambda \beta>1$. Together, these two inequalities imply that the firm adds value to the cash prices as well: $\lambda>1$. The last (technical) condition makes the problem less trivial. If the firm were too productive $\lambda>2$, renegotiation would always postpone debt service. The gains from another round of production would be so large that they would always overcome the transformation risk (i.e. F's diversion of cash $m_{1}$ for current consumption).

2. F has all bargaining power. This is again a simplifying assumption. We give all the bargaining power to the firm in order to show that even if $F$ is the residual claimant, cash may still be expropriated which would provide incentives for barter.

3. Parties have symmetric information: creditors are perfectly aware that their rights might be violated. The problem we are dealing with is a problem of enforcement, which can be analysed within the framework of incomplete contracts. C knows that there is no mechanism to enforce a contract that obliges $\mathrm{F}$ to use cash for buying inputs rather than for personal consumption.

4. Cash has the same value for both parties but barter can only be used as an input in production using the technology owned by $\mathrm{F}$. Technology is inalienable. Even if $\mathrm{F}$ breaches the debt contract, $\mathrm{C}$ cannot take control of the productive assets. ${ }^{15}$

\footnotetext{
${ }^{14}$ This condition is related to the fact that we only have two periods. If there were $T$ periods, the constraint would be $\lambda<T$.

${ }^{15}$ The conventional explanation of this assumption lies in the inalienable nature of human capital. Although it may be applicable to Russia, we have in mind a much bigger problem: the absence of effective bankruptcy procedures. In Russia, creditors have a hard time claiming the assets of bankrupt firms (see Sonin and Zhuravskaya (2000)). Thus even physical capital is inalienable. Certainly, it is much easier for creditors to get hold of liquid assets (cash).
} 


\subsection{The first best}

Apparently, the social optimum is to sell for cash, buy one unit of input and produce at maximum capacity. In other words, $b=0, m_{0}=1, q=1, m_{2}=\lambda q$. Social welfare equals $\lambda$.

There are three potential sources of inefficiency in the model. First, selling for barter rather than for cash. Barter sales involve transaction costs $(1-\beta) b$. The second source of inefficiency is the failure of debt renegotiations: if $\mathrm{C}$ takes all the cash $\mathrm{F}$ has at $t=1, \mathrm{~F}$ produces below social optimum $q<1$, and therefore a dead weight loss $(\lambda-1)(1-q)$ arises.

The third problem is the cash diversion (transformation) risk: even if debt payments are postponed and $\mathrm{F}$ keeps some cash, $\mathrm{F}$ may prefer to spend it for consumption right away rather than to purchase inputs. As in Myers and Rajan (1998) we assume that the more liquid the asset is, the higher the transformation risk is. A manager has more discretion in using liquid assets, and therefore outside investors have less control over the manager the more liquid the assets are. The transformation risk often appears in literature on incomplete financial contracts where the only contractible variable is the payment from one party to the other, while the levels of inputs and outputs are not contractible. In our model, the manager can easily transform cash for his private benefit while the in-kind payments (inputs) can only be used for production.

The first best can be implemented if there is effective bankruptcy legislation. ${ }^{16}$ Indeed, let us assume for a moment, that Assumption 4 does not hold. Thus, if $\mathrm{F}$ does not pay $\mathrm{C}, \mathrm{C}$ can replace the manager and manage the firm himself. Then $\mathrm{F}$ knows that selling for barter will not help: if $\mathrm{F}$ sells for barter so that there is not enough cash to repay the debt, $\mathrm{C}$ takes over. $\mathrm{C}$ uses the inputs $b$ for production, and the previous manager gets nothing.

\subsection{No renegotiations}

Let us first study what happens if renegotiation at $t=1$ is not allowed. We will solve the model via backward induction. First, we will find $m_{2}$ under given $x, P, D_{1}, m_{0}$ and $b$. Second, we will determine $x$ given $P, D_{1}, m_{0}$ and $b$. Then we will find $P$ and $D_{1}$, given $m_{0}$ and $b$. Finally, we will describe the choice of $m_{0}$ and $b$. The ultimate goal of our analysis is to establish to what extent the choice between money and barter depends on debt $D_{0}$.

The choice between money and barter at $t=2$ is trivial. Since parter can only be used for production, it makes no sense to sell in the last period for barter. ${ }^{1}$ Hence, $m_{2}=\lambda q$.

The amount of inputs bought for cash $x \in\left[0, m_{0}-P\right]$ is chosen by the firm to maximise $U^{F}=m_{0}-P-x+\left[\lambda \beta \mathrm{b}+\lambda x-D_{1}\right]_{+}$.

This function is convex with regard to $x$. Therefore the solution must be a corner one: either $x=0$ or $x=m_{0}-P$. Let us check when F prefers $x=m_{0}-P$. Using all available cash to buy inputs provides $\mathrm{F}$ with a higher payoff whenever $\left[\lambda \beta b+\lambda\left(m_{0}-P\right)-D_{1}\right]_{+} \geq m_{0}-P+[\lambda \beta b-$ $\left.D_{1}\right]_{+}$. Since $m_{0}-P \geq 0$, this condition is equivalent to:

$\lambda \beta b-D_{1}+(\lambda-1)\left(m_{0}-P\right) \geq 0$.

\footnotetext{
${ }^{16}$ Formally, another simple solution is to write off the debt. Certainly, this does not satisfy C's individual rationality constraint.

${ }^{17}$ This is due to the finite horizon setting.
} 
Let us find the first-period payments $P$ and the second period debt $D_{1}$. Since there are no renegotiations, $P=\min \left\{m_{0}, D_{0}\right\}$ and $D_{1}=\left[D_{0}-m_{0}\right]_{+}$. Now we can describe the choice between money and barter. The firm chooses $b$ and $m_{0}$ to maximise (2) subject to $b+m_{0} \leq 1$. There can be 2 cases:

1. The firm gets enough cash revenues to pay off the initial debt: $m_{0} \geq D_{0}$. In this case $P=D_{0}$ and $D_{1}=0$. Inequality (3) holds, so that $x=m_{0}-P$ and the firm's payoff (2) becomes $U^{F}=\lambda$ $\beta \mathrm{b}+\lambda\left(m_{0}-D_{0}\right)$. Since $\beta<1$, the firm is better-off selling for cash as much as possible: $m_{0}=1$ and $b=0$. Apparently, this case is only possible if $D_{0} \leq 1$. F's utility is $U^{F}{ }_{\mathrm{m} 0=1}=\lambda(1-$ $\left.D_{0}\right)$.

2. The firm does not have enough cash revenues to repay the debt: $m_{0}<D_{0}$. It has to pay all the cash to the creditor: $P=m_{0}$, and $D_{1}=D_{0}-m_{0}$, and is left with no cash to buy inputs $x=0$. The firm's payoff $(2)$ becomes $U^{F}=\left[\lambda \beta b+m_{0}-D_{0}\right]_{+}$. Since $\lambda \beta>1$, the firm is betteroff selling everything for barter: $m_{0}=0$ and $b=1$. Thus the firm gets $U^{F}{ }_{\mathrm{b}=1}=\left[\lambda \beta-D_{0}\right]_{+}$.

Comparing the two cases we see that the firm is better-off selling for barter whenever debt is sufficiently high (see Figure 2).

Proposition 1. In the model without renegotiation, the firm chooses to sell all its output for barter $U^{F}{ }_{b=1} \geq U^{F}{ }_{m 0=1}$ if and only if $D_{0} \geq D^{*}=\lambda(1-\beta) /(\lambda-1)$. Otherwise, the firm sells all its output for cash.

The Proposition is quite intuitive. Indeed, if there are no renegotiation, the creditor will seize all the cash that the firm gets for its sales. Stripped of the working capital, the firm would not be able to continue production at a reasonably high level. In order to protect its working capital, the firm chooses to hide the revenues from the creditor via selling for barter. Although inefficient $(\beta<1)$, barter makes it possible to avoid the expropriation of working capital while facilitating buying inputs. Being able to produce in the second period, the firm gets cash and partially or fully repays the debt. 


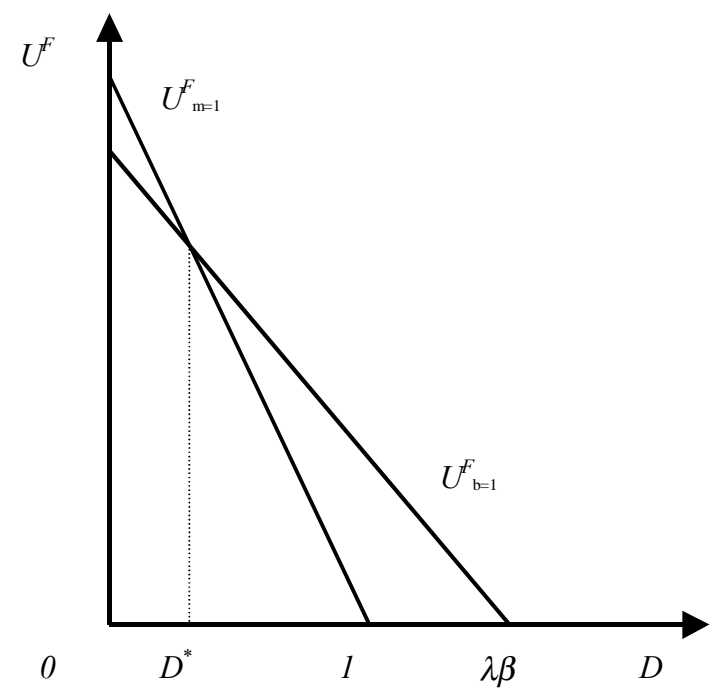

Figure 2. Firm's payoff as a function of outside debt in the model without renegotiation.

\subsection{The model with renegotiations}

The model above assumes that renegotiation is not allowed and that the creditor seizes all the cash the firm has at $t=1$. Apparently, this may be myopic: by restructuring the debt, the creditor would encourage the firm to produce more in the next period. This, in turn, would increase the creditor's chances of getting his money back. Debt restructuring may therefore provide the ex ante incentives for the firm to sell for cash rather than for barter. F knows that $\mathrm{C}$ will not expropriate all the cash right away, so there is no need to hide revenues in the form of barter and to pay for the cost of barter. In this Section, we study a model with renegotiation and check to which extent renegotiation may help to reduce barter.

Again, we will solve the model via backward induction. Apparently, the choice of $m_{2}$ and $x$ under given $P, D_{1}, m_{0}$ and $b$ are the same as in the previous Section. In the second period, $\mathrm{F}$ sells for cash: $m_{2}=\lambda q$. The amount of inputs bought for cash is $x=m_{0}-P$ whenever (3) holds and $x=0$ otherwise.

Now consider the debt renegotiation. The firm and the creditors bargain on $P$ and $D_{1}$ to maximise the joint surplus of $\mathrm{F}$ and $\mathrm{C}$ at the date $t=1$. At this point, the choice between money and barter $m_{0}$ and $b$ has already been made, so that the renegotiation only effects the last period of debt overhang and therefore F's incentives to produce more output. If $P$ and $D_{1}$ are such that (3) holds, then F uses the remaining cash - if any is left - to buy inputs and produce more. Otherwise the manager immediately diverts the remaining cash for personal consumption and only uses inputs already bought for barter. The parties' payoffs calculated at $t=1$ are as follows:

1. Inequality (3) holds (no diversion):

$U^{C}=P+\min \left\{\lambda \beta b+\lambda\left(m_{0}-P\right), D_{1}\right\} ; U^{F}=\left[\lambda \beta b+\lambda\left(m_{0}-P\right)-D_{1}\right]_{+}$ 
2. Inequality (3) does not hold (diversion):

$U^{C}=P+\min \left\{\lambda \beta b, D_{1}\right\} ; U^{F}=m_{0}-P+\left[\lambda \beta b-D_{0}+P\right]_{+}$

Since $\mathrm{F}$ has all the bargaining power, $\mathrm{F}$ chooses $P$ and $D_{1}$ to maximise $U^{F}$ subject to the creditor's participation constraint $U^{C} \geq m_{0}+\min \left\{\lambda \beta b, D_{0}-m_{0}\right\}$.

It is easy to show that case 2 is not relevant. The aim of renegotiation is to postpone debt payments to leave some cash for input purchases. If the firm uses the cash for current consumption and if $x=0$, then there is no case for renegotiation. Thus, the second case will never occur in equilibrium. To make sure that it does not happen, the parties will agree on a contract $P, D_{1}$ that satisfies the constraint (3) and therefore prevents the firm from diverting the cash. Unfortunately, the constraint (3) may be binding which may distort the choice of $\mathrm{P}$, $\mathrm{D}_{1}$ : the diversion never happens but the threat of diversion may prevent the parties from achieving the first best.

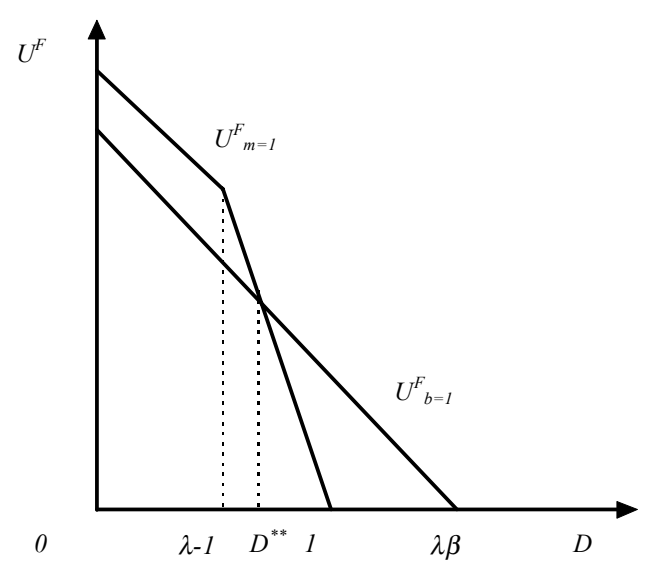

Figure 3. Firm's payoff as a function of outside debt in the model with renegotiation.

Formally, F chooses $P, D_{1}$ to maximise:

$$
\left[\lambda \beta b+\lambda\left(m_{0}-P\right)-D_{1}\right]_{+}
$$

subject to (3) and the creditor's individual rationality constraint:

$P+\min \left\{\lambda \beta b+\lambda\left(m_{0}-P\right), D_{1}\right\} \geq m_{0}+\min \left\{\lambda \beta b, D_{0}-m_{0}\right\}$.

The solution to this problem is $P=(2-\lambda)^{-1}\left[m_{0}+\min \left\{\lambda \beta b, D_{0}-m_{0}\right\}-\lambda \beta b-(\lambda-1) m_{0}\right]_{+}, D_{1}=m_{0}+$ $\min \left\{\lambda \beta b, D_{0}-m_{0}\right\}-P$. Thus, whenever $m_{0}+\min \left\{\lambda \beta b, D_{0}-m_{0}\right\}>\lambda \beta b+(\lambda-1) m_{0}$, renegotiation results in $P>0$. Some cash is used to pay off the debt rather than to buy inputs. This provides $\mathrm{F}$ with the wrong incentives: indeed, selling for cash, $\mathrm{F}$ would lose some of its working capital and therefore would not be able to produce as much as it could if it had sold its output for barter. Notice that $\mathrm{P}>0$ holds if and only if constraint (3) is binding ${ }^{\mathrm{L}}$ _ if there

\footnotetext{
${ }^{18}$ In particular, if $\lambda>2$ were the case, the condition (3) would not bind, and the solution would always be $\mathrm{P}=0, D_{1}$ $=m_{0}+\min \left\{\lambda \beta b, D_{0}-m_{0}\right\}$. If the firm is very productive, renegotiation always postpones debt service: the gains of another round of production are so large that they always overcome the transformation risk (i.e. F's diversion
} 
were no risk of cash diversion, the parties would postpone all debt payments $\mathrm{P}=0$. The suboptimal outcome $\mathrm{P}>0$ occurs only when constraint (3) is binding ${ }^{\text {IT }}$.

Substituting $P, D_{1}$ into (4), we obtain the firm's payoff as a function of $b$ and $m_{0}$

$U^{F}=m_{0}+\left(\left[\lambda \beta b+m_{0}-D_{0}\right]_{+}-(2-\lambda) m_{0}\right)-(2-\lambda)^{-1}(\lambda-1)\left[(2-\lambda) m_{0}-\left[\lambda \beta b+m_{0}-D_{0}\right]_{+}\right]_{+}(5)$

The firm chooses $b$ and $m_{0}$ to maximise (5) subject to $b+m_{0} \leq 1$. Apparently, (5) increases with both $b$ and $m_{0}$, so that this constraint is binding $b+m_{0}=1$. Substituting $b=1-m_{0}$, we obtain a convex function of $m_{0}$. Therefore the solution is always a corner one: either sell everything for cash $m_{0}=1$ or sell everything for barter $m_{0}=0$. If $\mathrm{F}$ sells everything for barter it gets $U^{F}$ $\mathrm{b}=1=\left[\lambda \beta-D_{0}\right]_{+}$. If F sells everything for cash, it gets $U^{F}{ }_{\mathrm{m} 0=1}=1+\left(\left[1-D_{0}\right]_{+}-(2-\lambda)\right)-(2-\lambda)^{-1}(\lambda-$ 1) $\left[(2-\lambda)-\left[1-D_{0}\right]_{+}\right]_{+}$.

Figure 3 shows $U^{F}{ }_{\mathrm{b}=1}$ and $U^{F}{ }_{\mathrm{m} 0=1}$ as functions of the initial debt $D_{0}$. One can easily show that $U^{F}{ }_{\mathrm{b}=1}>U^{F}{ }_{\mathrm{m} 0=1}$ if and only if $D_{0}>D^{* *}=(1-\lambda \beta(2-\lambda)) /(\lambda-1)$.

Proposition 2. In the model with renegotiation, the firm chooses to sell all its output for barter $U^{F}{ }_{\mathrm{b}=1} \geq U^{F}{ }_{\mathrm{m} 0=1}$ if and only if $D_{0} \geq D^{* *}=(1-\lambda \beta(2-\lambda)) /(\lambda-1)$. Otherwise, the firm sells all its output for cash. In the presence of renegotiation, barter is less likely: $D^{*}<D^{* *}$.

The Proposition implies that the introduction of renegotiation makes barter less likely: if $D_{0} \in$ $\left(D^{*}, D^{* *}\right)$ barter does not occur in the presence of renegotiation but it would occur if renegotiation were not allowed.

Thus, renegotiation reduces barter but does not eliminate it altogether. Why is this? The key is the cash diversion risk: the firm's manager cannot ensure he will not divert cash for current consumption rather than for purchasing inputs. The reason why the firm's manager may be interested in diversion is the remaining debt overhang. If the debt is rescheduled, and the second-period debt burden is too high, the firm expects to receive too little of the cash revenues $m_{2}$. Therefore diversion is likely to happen. Diversion can be prevented by reducing the second period debt overhang, but this is costly. To compensate the creditor for the lower second-period return, $\mathrm{F}$ has to pay more in the first period which in turn provides $\mathrm{F}$ with the wrong ex ante incentives: $\mathrm{F}$ knows that it will have to pay something in the first period and will prefer to have as little cash and as much barter as possible.

\subsection{Bubble}

The analysis above shows that renegotiation may help to decrease barter. However, renegotiation does not always occur. One explanation is the famous free-rider problem. If there are many creditors, then it will be hard for them to agree on the renegotiation outcome since each of them will want a free ride at the others' expense. Another important explanation of the failure of renegotiation to eliminate barter may be the presence of a financial bubble that pays a high real interest rate. During 1995-98, the Russian government bond (GKO) market paid out very high real returns. Since the bubble burst in August 1998, barter levels have been steadily decreasing. We will introduce the GKO market in the following way.

Suppose that the creditor has an investment opportunity that pays off a gross interest rate $\delta>\lambda$. The firm does not have access to this opportunity. At the time of renegotiation, the parties

of cash $m_{1}$ for current consumption): the relationships between barter and debt vanish.

${ }^{19}$ Constraint (3) assures that the utility derived from buying inputs with all cash available is higher than that derived from diverting cash and financing all production through barter: in other words, there is no risk of cash diversion. If the constraint is binding, it means that the parties cannot agree on postponing all debt payments, because a threat of diversion exists. 
expect the following payoffs:

$$
U^{C}=P+\delta^{-1} \min \left\{m_{2}, D_{1}\right\}, \quad U^{F}=m_{1}-x+\left[m_{2}-D_{1}\right]_{+}
$$

Solving the model by backward induction, we obtain the equilibrium which is equivalent in real terms to the equilibrium without renegotiation. Indeed, $m_{2}=\lambda q, x=m_{0}-P$ if (3) holds and $x=0$ otherwise. The renegotiation ends up with $P=\min \left\{m_{0}, D_{0}\right\}$ and $D_{1}=\left[D_{0}-m_{0}\right]_{+}$. Indeed, C is not interested in the second period payments unless $\mathrm{F}$ offers $\delta$ second-period rubles for each first-period one. But this does not happen: F's internal rate of return is $\lambda$. Thus, the choice between money and barter at $t=0$ is precisely the same as in the model without renegotiation.

Certainly, stripping the firm of its working capital and buying the bonds is locally efficient: the coalition of $\mathrm{F}$ and $\mathrm{C}$ makes more money via investing in GKO rather than through buying inputs and producing. We should not forget, though, that $\delta$ is not a market rate of return. Rather, it is a growth rate of a bubble. The cost of capital in the economy is still normalised to one, and therefore redirecting the cash from the real sector to the bond market is not efficient for the economy as a whole.

\section{Empirical results}

\subsection{The empirical strategy}

The model in Section 2 predicts a positive relationship between the level of outside debt and the share of barter in sales. Therefore, controlling for other explanations of barter, we should expect indebted firms to resort to barter more often. We run OLS estimates for the share of barter in sales for two firm-level datasets: the Russian Economic Barometer (REB) survey and the Barter in Russian Industrial Firms (BRIF) dataset (IET survey matched with the Goskomstat database of Russian firms). The indepedendent variables are debt as a ratio of annual sales in the beginning of the period, regional and industry dummies, size and share in exports.

Our theory predicts that the relationship between debt and barter should be observed if the firm is not too indebted. If the debt is very high (e.g. $D_{0}>\lambda \beta$ ) then barter does not help to protect the working capital and any further increase in debt does not result in more barter. We will therefore run separate tests for the most indebted sub-samples.

We will also control the main alternative explanation of the positive relationship between debt and barter: that is that both debt and barter occur mostly in 'bad' firms. In the presence of the soft budget constraint, credit is allocated to bail out loss-making firms. E. Berglof and G. Roland (1998) emphasise the ex post injection of soft credit from banks to firms, which should be liquidated ${ }^{21}$. As a result, bank credit is allocated to loss makers. The healthier firms have little access, if any, to external finance 22 , also, they tend to repay debt while lossmaking firms remain indebted. On the other hand, less productive firms are also less competitive in the cash market and are doomed to sell their output through the old networks.

\footnotetext{
${ }^{20}$ Certainly, this is not a closed and consistent model with rational players: we have just looked at one end of the GKO cash flows. Building a general equilibrium of a Ponzy game is however not the purpose of this paper. We can only say that somewhere in the public or private sector, there must have been irrational traders who supported the high rate of return.

${ }^{21}$ The crucial point is that, if the proportion of bad loans is high enough, the ex post benefits of bailing out are higher than the benefits of liquidation.

${ }^{22}$ One reason suggested in S. Brana and M. Maurel (1999) is that in the presence of adverse selection, credit is rationed, healthier firms do not borrow.
} 
Therefore they sell more through barter. To control this explanation of the link between barter and indebtedness, we estimate a system of three simultaneous equations.

In the first equation, we estimate the dependence of indebtedness on productivity (controlling for size, regional and industry dummies). We use the following proxies of productivity: the decline of the firm's output over the whole period of transition prior to the year for which we run the regression, and the rate of capacity utilisation. Both capture the extent to which the firm can add value in the market rather than command economy prices. According to the soft budget constraint theory, a decrease in prgductivity should lead to liquidation, but if the benefit of bailing out is higher for the bank ${ }^{\mathrm{L}_{2}}$, then indebtedness increases.

In the second equation, we estimate the dependence of barter on the rate of capacity utilisation (again, controlling for other determinants of barter). This makes it possible to take into account the fact that less competitive firms are less involved in the cash market and therefore use barter more freely.

Given these two equations, we test whether the relationship between indebtedness and barter is still significant. This is our third equation.

\subsection{Data description}

The REB is a survey which has been conducted since 1992 . On a quarterly basis (REB quarterly survey), a sub-sample of the survey has been obtained for 1995 and 1996 only. About 170 to 210 firms considered representative in terms of geographic as well as sector localisation answer the REB quarterly questionnaire. An important bias is the predominance of privatised firms, as opposed to new private firms. In the 1996 sample, 18\% were stateowned, $26 \%$ had a mixed property structure, and $56 \%$ were privatised former state-ownedenterprises.

The variables we used are summarised in Table A1 in the Appendix; they are either expressed in per cent of a monthly usual current level $(b r, u t c)$ or with respect to a previous level set equal to $100(\mathrm{~d} t 0)$ :

The REB barter variable $b r$ is the current share of barter in sales (as a percentage), for each firm at each time ( $t$ varies from $t=$ first quarter of 1995 to $t=$ last quarter of 1996). The proxy for indebtedness $d t 0$ is the level of indebtedness towards banks, the level six months ago being set equal to 100 . The output decline is captured by the capacity utilisation rate utc. The higher the utc is the more competitive the firm is in the market economy.

We shall also use the dataset Barter in Russian industrial firms (BRIF) built in the New Economic School Research Project " Non-Monetary Transactions in Russian Economy ". This dataset was created by matching the surveys of managers of Russian industrial firms conducted in 1996-98 by Serguei Tsoukhlo (Institute of Economies in Transition, Moscow) with the Goskomstat database of Russian firms (Federal Committee of Statistics of Russian Federation). Since Goskomstat data was most complete for 1996 and 1997 we ran regressions for the 1996 and 1997 data.

The barter data included six to seven hundred firms each year. The barter data is comprised of

\footnotetext{
${ }^{23}$ The benefit can be higher if there are strong interdependencies between enterprises (too many to fail), if the quality of competing projects is poor, if bank develop rent seeking activities for exploiting the softness of government etc.

${ }^{24}$ For a more detailed presentation of the survey, see The Russian Economic Barometer publication, any volume.
} 
the answers given by firms' managers to the following (eight) questions: " how much of your firm's inputs (outputs) were paid in rubles, in dollars, in kind and in promissory notes? " The Goskomstat database includes compulsory statistical reports that all large and medium-size firms must submit to the Russian Federal Statistics Committee. There are over 16 thousand firms in the database. However, there are many missing items in the financial accounts. After matching barter data with the Goskomstat data we ended up with roughly three hundred observations in each year among which only about a hundred firms appeared both in 1996 and 1997.

As a proxy of debt we take the firm's total indebtedness in the beginning of the corresponding year divided. This variable (sum of line items 610 and 620 in the balance sheet) includes bank loans (610) and amounts owed to suppliers, subsidiaries, consolidated government, IOU holders, employees and other creditors (620).

In order to control for other explanations of barter we also include firms' size, export and market power, as well as regional and industry dummies in our regressions. As a proxy of size we take logarithm of annual sales. As for exports, we include share of exports in sales. The summary statistics and pairwise correlations are provided in Tables A3 and A4 in the Appendix. We also included regional and 2-digit industry dummies. are described in Table A5. As for the regions, we have only introduced dummies for Moscow and seven presidential districts but only Moscow's, Urals' and Siberia's dummies came out significantly different from the European Russia which we used as the base category.

\subsection{Evidence from REB survey}

The results of the OLS regressions for barter are presented in the Table 1. In addition to indebtedness we also control the firm's size, measured as a number of employees (lab), and include regional and industry dummies. When we estimate the effect of indebtedness on the whole sample, the coefficient is positive but not significant. Our theory predicts that the coefficient must be significant if the firms are not too indebted. We exclude firms with $\mathrm{dt} 0<200$ (16 firms or less than six per cent of the sample) and indeed obtain a positive and significant coefficient.

Table 1: OLS regressions with robust standard errors

\begin{tabular}{|l|l|l|}
\hline Barter & Whole sample & $d t 0<200$ \\
\hline$d t 0$ & $0.011(0.010)$ & $0.13 * * *(0.024)$ \\
\hline lab & $0.003 * * *(0.001)$ & $0.002 * *(0.001)$ \\
\hline $\begin{array}{l}\text { Regional and } \\
\text { industry dummies }\end{array}$ & $* * *$ & $* * *$ \\
\hline Constant & $22.37 * * *(6.22)$ & $20.44 * * *(6.62)$ \\
\hline $\mathrm{N}$ & 261 & 245 \\
\hline $\mathrm{R} 2$ & 0.42 & 0.41 \\
\hline
\end{tabular}

*** - significance at $1 \%$ level, $* *$ - significance at $5 \%$ level, $*$ - significance at $10 \%$ level

\footnotetext{
${ }^{25}$ To make the evidence from the two datasets comparable we have not used 5-digit industry information such as concentration ratios and consumer goods indexes. Including them in the regressions does not change the results. See Guriev and Kvassov (2000) on the effect of these variables on barter.
} 
Table 2 presents the estimations of the simultaneous equation model. We do find that when controlling for the negative relationship between indebtedness and capacity utilisation and the negative relationship between barter and capacity utilisation, barter still positively and significantly depends on capacity utilisation.

Table 2: Simultaneous equation model

\begin{tabular}{|l|l|l|}
\hline Barter & Whole sample & $d t 0<200$ \\
\hline 1. Barter & & \\
\hline Utc & $-0.13 * * *(0.038)$ & $-0.13 * *(0.042)$ \\
\hline lab & $0.002 * *(0.0008)$ & $0.003 * * *(0.001)$ \\
\hline $\begin{array}{l}\text { Regional and } \\
\text { industry dummies }\end{array}$ & $* * *$ & $* * *$ \\
\hline Constant & $32.68 * * *(4.88)$ & $29.10 * * *(5.59)$ \\
\hline 2. Debt & & \\
\hline Utc & $-0.75 * * *(0.22)$ & $-0.25 * *(0.11)$ \\
\hline lab & $0.015 * * *(0.005)$ & $0.009 * * *(0.003)$ \\
\hline $\begin{array}{l}\text { Regional and } \\
\text { industry dummies }\end{array}$ & $* * *$ & $* * *$ \\
\hline Constant & $98.27 * * *(29.76)$ & $59.31 * * *(15.14)$ \\
\hline 3. Barter & & \\
\hline Debt & $0.14 * * *(0.04)$ & $0.38 * * *(0.08)$ \\
\hline Constant & $19.60 * * *(3.92)$ & $5.16(6.16)$ \\
\hline & & 243 \\
\hline N & 286 & \\
\hline
\end{tabular}

$* * *$ - significance at $1 \%$ level, $* *$ - significance at $5 \%$ level, $*$ - significance at $10 \%$ level

The results again support the model. Less productive firms are more indebted; when a firm faces an increase in its rate of capacity utilisation, barter decreases; finally the correlation between indebtedness and barter is positive, as predicted by the model, even controlling for the first two relationships. The latter correlation is higher and more consistent in the simultaneous equation model rather than in OLS regressions.

\subsection{Evidence from IET survey}

We run OLS regressions for barter for 1996 and 1997. The results of the estimations are shown in the Table 3. As our model predicts, barter positively and significantly depends on debt. Moreover, when we exclude the most indebted firms, the effect becomes stronger and the coefficient becomes more significant. 
Table 3: OLS regressions with robust standard errors

\begin{tabular}{|l|l|l|l|l|}
\hline Barter & $\begin{array}{l}1996 \\
\text { whole sample }\end{array}$ & $\begin{array}{l}1996 \\
\text { debt<1 }\end{array}$ & $\begin{array}{l}1997 \\
\text { whole sample }\end{array}$ & $\begin{array}{l}1997 \\
\text { debt<1 }\end{array}$ \\
\hline Debt & $0.06^{* *}(0.03)$ & $0.12 * *(0.06)$ & $0.03^{* *}(0.01)$ & $0.17 * * *(0.05)$ \\
\hline Log sales & $0.016(0.011)$ & $0.011(0.011)$ & $0.007(0.009)$ & $0.003(0.010)$ \\
\hline Exports & $-0.20 * * *(0.07)$ & $-0.22^{* * *}(0.07)$ & $-0.33 * * *(0.11)$ & $-0.39 * * *(0.14)$ \\
\hline $\begin{array}{l}\text { Regional and } \\
\text { industry dummies }\end{array}$ & $* * *$ & $* * *$ & $* * *$ & $* * *$ \\
\hline Constant & $.05(0.24)$ & $0.15(0.24)$ & $0.22(0.25)$ & $0.25(0.27)$ \\
\hline $\mathrm{N}$ & 289 & 275 & 315 & 270 \\
\hline $\mathrm{R} 2$ & 0.31 & 0.32 & 0.34 & 0.38 \\
\hline
\end{tabular}

$* * *$ - significance at $1 \%$ level, $* *$ - significance at $5 \%$ level, $*$ - significance at $10 \%$ level

Table 4 presents the results of estimations of the simultaneous equation model. Capacity utilisation has a negative and significant effect on both debt and barter, but even controlling for those effects, barter still positively and significantly depends on debt. Moreover, when the most indebted firms are excluded, the effect is much stronger.

Table 4 : Simultaneous equation model

\begin{tabular}{|l|l|l|l|l|}
\hline Barter & $\begin{array}{l}1996 \\
\text { whole sample }\end{array}$ & $\begin{array}{l}1996 \\
\text { debt<1 }\end{array}$ & $\begin{array}{l}1997 \\
\text { whole sample }\end{array}$ & $\begin{array}{l}1997 \\
\text { debt<1 }\end{array}$ \\
\hline 1. Barter & & & & \\
\hline Utc & $-0.03 * *(0.01)$ & $-0.05 * *(0.02)$ & $-0.04 * * *(0.02)$ & $-0.06 * * *(0.02)$ \\
\hline Log sales & $0.006(0.007)$ & $0.023(0.010)$ & $-0.003(0.007)$ & $-0.012(0.008)$ \\
\hline Exports & $-0.05(0.05)$ & $-0.10 *(0.06)$ & $-0.04(0.06)$ & $-0.15 * *(0.07)$ \\
\hline $\begin{array}{l}\text { Regional and } \\
\text { industry dummies }\end{array}$ & $* * *$ & $* * *$ & $* * *$ & $* * *$ \\
\hline Constant & $0.24 *(0.13)$ & $-0.09(0.17)$ & $0.50 * * *(0.13)$ & $0.21 * * *(0.15)$ \\
\hline 2. Debt & & & & \\
\hline Utc & $-0.12 * * *(0.04)$ & $-0.05 * *(0.02)$ & $-0.30 * * *(0.11)$ & $-0.09 * * *(0.03)$ \\
\hline Log sales & $-0.004(0.022)$ & $0.024 * *(0.010)$ & $-0.10^{* *}(0.04)$ & $-0.020 *(0.012)$ \\
\hline Exports & $-0.03(0.14)$ & $-0.07(0.06)$ & $0.83 * *(0.34)$ & $-0.02(0.11)$ \\
\hline $\begin{array}{l}\text { Regional and } \\
\text { industry dummies }\end{array}$ & $* * *$ & $* * *$ & $* * *$ & $* * *$ \\
\hline
\end{tabular}

\footnotetext{
${ }^{26} \mathrm{We}$ have also run regressions excluding the most productive firms (i.e. firms with the highest utc) and found that removing these firms does make the effect stronger as the model predicts.
} 


\begin{tabular}{|l|l|l|l|l|}
\hline Constant & $0.27 * * *(0.07)$ & $-0.29 *(0.17)$ & $2.42 * *(0.84)$ & $-0.10(0.27)$ \\
\hline 3. Barter & & & & \\
\hline Debt & $0.23 * * *(0.07)$ & $0.97 * * *(0.17)$ & $0.11 * * *(0.03)$ & $0.55 * * *(0.15)$ \\
\hline Constant & $0.32 * * *(0.02)$ & $0.19 * * *(0.04)$ & $0.36 * * *(0.02)$ & $0.28 * * *(0.04)$ \\
\hline & & & & \\
\hline $\mathrm{N}$ & 286 & 273 & 311 & 267 \\
\hline
\end{tabular}

\section{Conclusions}

In this paper, we have studied the relationship between indebtedness and barter in Russian firms. One interesting feature of the model is that it draws a link between the liquidity shortage argument and that of poor creditor right protection. Our model incorporates the argument that barter helps to protect working capital needed for sustaining production and the argument that barter comes as a strategic reaction of managers that may be costly for outside investors.

We explicitly model the possibility of relaxing the liquidity constraint by re-financing debt. Since the firm has a liquidity rather than a solvency problem, replenishing its working capital is socially efficient, so debt restructuring should be in the mutual interest of the firm and the creditors. However, the creditors face a difficult choice: postponing too much of the debt will provide incentives for the manager to divert cash rather than to finance the firm's working capital. Therefore the lack of any commitment not to divert cash becomes a constraint for debt restructuring. If debt overhang is too high, the negotiation fails and the debt is not restructured. This, in turn, provides ex ante incentives for the manager to prefer barter although barter involves higher transaction costs.

Another explanation for the failure of debt restructuring is the presence of the government bonds (GKO) bubble in 1995-1998. If the outside investment opportunity (GKO) yields a very high real interest rate, creditors will not be interested in refinancing the debt, which in turns provides managers with the incentives to use barter.

Our empirical analysis supports the predicted positive relationship between indebtedness and barter. Which of the two explanations of this relationship (the threat of cash diversion by the manager or the GKO bubble) is correct? Both are consistent with macro-economic evidence. The period of the highest GKO yields coincided with the highest levels of barter. Moreover, as the causality test in Brana and Maurel (1999) shows, higher real interest rates caused higher barter in 1995-98. On the other hand, the meltdown of August 1998 destroyed the GKO bubble bringing real interest rates to reasonably low levels. As one should have expected, barter has declined, too. But it has not disappeared altogether and is still much higher than in other economies.

Our model implies that hardening the bankruptcy procedures would have different effects in the presence and in the absence of a bubble. If the bubble is present, lack of bankruptcy leads to barter, which is definitely less efficient than money, but helps to protect the firm's working capital. Barter is a survival strategy that helps firms with high indebtedness to survive and keep producing. The returns on production are lower than the GKO yield but since the latter is the bubble, production may be socially efficient. On the other hand if there is no bubble, 
lack of effective bankruptcy procedures and creditor rights protection results in barter which is simply less efficient than monetary exchange. Our analysis suggests two policies that can decrease barter: (i) to avoid high-yield debt financing of the budget deficit and (ii) to continue the efforts to introduce effective bankruptcy procedures and protect creditor rights.

\section{References}

Aukutsionek S. (1998), "Industrial Barter in Russia", Communist Economies and Economic Transformation, Vol. 10, No. 2, 179-188.

Berglöf E. and Roland G. (1998), " Soft Budget Constraints and Banking in Transition Economies ", Journal of Comparative Economies, Vol. 26, 18-40.

Brana S. and Maurel M. (1999), "Barter in Russia: Liquidity Shortage Versus Lack of Restructuring", CEPR Discussion Paper No. 2258.

Carlin W., Fries S., Schaffer M. and Seabright P. (2000), "Barter and non-monetary transactions in transition economies: Evidence from a cross-country survey", EBRD Working paper No. 50.

Commander S., Mumssen C. (1998), "Understanding Barter in Russia", EBRD Working Paper, No. 37, December.

Drebentsov, V., Morozov, A. and B.Pinto (1999), " Dismantling Russia's Nonpayments System: Creating Conditions for Growth ", World Bank, Moscow.

Earle, John and Klara Sabirianova (1999), "Understanding Wage Arrears in Russia ", Working Paper No.139, Stockholm Institute of Transition Economies.

EBRD (1999), Transition Report. London.

Gaddy C. and Ickes B.W. (1998), "To Restructure or Not to Restructure: Informal Activities and Enterprise Behavior in Transition", The Davidson Institute Working Paper Series, No. 134.

Gelfer S., Pistor K. and Raiser M. (2000), " Law and Finance in Transition Economies", EBRD Working paper No. 48.

Guriev S. and Kvassov D. (2000), "Barter for Price Discrimination?", CEPR Discussion Paper No. 2449.

Guriev S. and B.Ickes, (2000), "Barter in Russia", in Paul Seabright, Ed, The Vanishing Ruble: Barter and Currency Substitution in post-Soviet Societies, Cambridge University Press.

Hart O. (1995), Firms, Contracts and Financial Structure, Oxford University Press.

Hendley K., Ickes B.W., Murrell P., Ryterman R. (1997), "Observations on the Use of Law by Russian Enterprises", Post-Soviet Affairs, Vol. 13, No. 1, 19-41.

Karpov P. (1997). "On the Causes of Tax Arrears, General Causes of the Payment Crisis and Plausibility of Financial Recovery of Russian Firms". Report of the Inter-Agency Balance Sheet Commission, Moscow. [In Russian].

Krugman, P. (1988), "Financing vs. Forgiving a Debt Overhang", Journal of Development Economics, Vol.29, 253-268. 
Kuznetsov, P., Gorobets G., and Fominykh A. (2000), "Barter and Non-Payments as a New Form of Industrial Organization in Russia," Report of the Working Center for Economic Reform, Moscow.

Linz S.J. and Krueger G. (1998), "Enterprise Restructuring in Russia's Transition Economy: Formal and Informal Mechanisms", Comparative Economic Studies, Vol. XXXX, No. 2, 5-52.

Marin D. and Schnitzer M. (1999), "Disorganization and Financial Collapse", CEPR Discussion Paper No. 2245.

Myers S. and Raghuram Rajan (1998), "The Paradox of Liquidity", Quarterly Journal of Economics.

Perotti E. and Carare O. (1997), " The Evolution of Bank Credit Quality in Transition: Theory and Evidence from Romania ", mimeo, Univ. Of Amsterdam.

Sonin, Constantin and Ekaterina Zhuravskaya (2000), " Bankruptcy in Russia -Away From Creditor Protection and Restructuring ", Russian Economic Trends, 9(1).

Yakovlev, A. (1999) "Black cash tax evasion in Russia: Its forms, incentives and consequences at firm level ", BOFIT Discussion Papers, No.3 


\section{Appendix: Tables}

Table A1 : REB: Summary statistics for the main variables in 1995 and 1996

\begin{tabular}{|l|l|l|l|l|l|l|l|l|}
\hline Variable & \multicolumn{3}{l|}{ Mean } & \multicolumn{2}{l|}{ Std. Dev. } & \multicolumn{2}{l|}{ Min } & \multicolumn{2}{l|}{ Max } \\
\hline Year & 1995 & 1996 & 1995 & 1996 & 1995 & 1996 & 1995 & 1996 \\
\hline br & 24,05 & 38,11 & 20,15 & 25,83 & 0 & 0 & 55 & 65 \\
\hline utc & 57,54 & 53,97 & 26,57 & 26,48 & 5 & 15 & 105 & 105 \\
\hline dt0 & 90,40 & 83,42 & 87,76 & 96,94 & 0 & 0 & 800 & 800 \\
\hline
\end{tabular}

Source: REB quarterly survey, June and December 1995 and 1996.

$\underline{\text { Table A2. REB: Pairwise correlations in } 1995 \text { and } 1996}$

\begin{tabular}{|l|l|l|l|l|l|l|}
\hline \multicolumn{2}{|l|}{ br } & \multicolumn{2}{l|}{ utc } & \multicolumn{2}{l|}{ dt0 } \\
\hline Year & 1995 & 1996 & 1995 & 1996 & 1995 & 1996 \\
\hline br & 1 & 1 & & & & \\
\hline utc & $-0,1586$ & $-0,0946$ & 1 & 1 & & \\
\hline dt0 & 0,2505 & 0,1399 & $-0,1077$ & $-0,0462$ & 1 & 1 \\
\hline
\end{tabular}

Source: REB quarterly survey, June and December 1995 and 1996.

Table A3. BRIF: Summary statistics.

\begin{tabular}{|l|l|l|l|l|l|}
\hline Variable & Explanation & Mean & Std. Dev. & Min & Max \\
\hline Barter_96 & $\begin{array}{l}\text { Share of barter in } \\
\text { sales, 1996 }\end{array}$ & 0.37 & 0.24 & 0 & .83 \\
\hline Barter_97 & $\begin{array}{l}\text { Share of barter in } \\
\text { sales, 1997 }\end{array}$ & 0.42 & 0.25 & 0 & .83 \\
\hline Debt96 & $\begin{array}{l}\text { Debt as of Jan 1, } \\
\text { 1996 divided by } \\
\text { annual sales }\end{array}$ & 0.28 & 0.48 & 0 & 5.07 \\
\hline Debt97 & $\begin{array}{l}\text { Debt as of Jan 1, } \\
\text { 1996 divided by } \\
\text { annual sales }\end{array}$ & 0.61 & 2.02 & 0 & 31.6 \\
\hline Ls96 & $\begin{array}{l}\text { Log sales 1996 } \\
\text { Ls97 }\end{array}$ & 17.0 & 1.72 & 11.1 & 22.3 \\
\hline Export96 & $\begin{array}{l}\text { Share of export in } \\
\text { sales, 1996 }\end{array}$ & 0.084 & 0.166 & 0 & .97 \\
\hline Export97 & $\begin{array}{l}\text { Share of export in } \\
\text { sales, 1997 }\end{array}$ & 0.063 & 0.146 & 0 & .97 \\
\hline
\end{tabular}


$\underline{\text { Table A4 BRIF The sample by 2-digit industries }}$

\begin{tabular}{|l|l|l|}
\hline & Industry & Number of firms \\
\hline Ind1 & Electricity & - \\
\hline Ind2 & Fuel & 8 \\
\hline Ind3 & Ferrous metals & 48 \\
\hline Ind4 & Non-ferrous metals & 17 \\
\hline Ind5 & Chemical and petro-chemical & 78 \\
\hline Ind6 & Machinery & 201 \\
\hline Ind7 & Pulp and forestry & 82 \\
\hline Ind8 & Construction materials & 76 \\
\hline Ind9 & Textile & 94 \\
\hline Ind10 & Food & 101 \\
\hline Ind11 & Other & 18 \\
\hline
\end{tabular}

Table A5: BRIF Pairwise correlations $(* * *$ denotes significance at $1 \%$ level, $* *$ denotes significance at 5\% level)

\begin{tabular}{|l|l|l|l|l|}
\hline & Barter_96 & Debt96 & Ls96 & Export96 \\
\hline & & & & \\
\hline Barter_96 & 1 & & & \\
\hline Debt96 & $0.25^{* * *}$ & 1 & & \\
\hline Ls96 & 0.11 & 0.10 & 1 & \\
\hline Export96 & 0.10 & $0.27 * * *$ & 0.1836 & 1 \\
\hline & & & & \\
\hline & Barter_97 & Debt97 & $1 s 97$ & export97 \\
\hline & & & & \\
\hline Barter_97 & 1 & & & \\
\hline Debt97 & $0.30 * * *$ & 1 & & \\
\hline ls97 & 0.09 & 0.06 & 1 & \\
\hline Export97 & -0.02 & $0.13^{* *}$ & $0.20 * * *$ & 1 \\
\hline
\end{tabular}




\section{DAVIDSON INSTITUTE WORKING PAPER SERIES}

CURRENT AS OF 10/13/00

\begin{tabular}{|c|c|c|}
\hline Publication & Authors & Date of Paper \\
\hline No. 339 Debt Overhang and Barter in Russia & $\begin{array}{l}\text { Sergei Guriev, Igor Makarov and Mathilde } \\
\text { Maurel }\end{array}$ & September 2000 \\
\hline $\begin{array}{l}\text { No. } 338 \text { Firm Performance and the Political } \\
\text { Economy of Corporate Governance: Survey } \\
\text { Evidence for Bulgaria, Hungary, Slovakia and } \\
\text { Slovenia }\end{array}$ & Patrick Paul Walsh and Ciara Whela & July 2000 \\
\hline No. 337 Investment and Instability & Nauro F. Campos and Jeffrey B. Nugent & May 2000 \\
\hline $\begin{array}{l}\text { No. } 336 \text { The Evolution of the Insurance } \\
\text { Sector in Central and Eastern Europe and } \\
\text { the former Soviet Union }\end{array}$ & Robert B.K. Pye & August 2000 \\
\hline $\begin{array}{l}\text { No. } 335 \text { Institutional Technology and the } \\
\text { Chains of Trust: Capital Markets and } \\
\text { Privatization in Russia and the Czech } \\
\text { Republic }\end{array}$ & Bruce Kogut and Andrew Spicer & August 2000 \\
\hline $\begin{array}{l}\text { No. } 334 \text { The Evolution of Market Integration } \\
\text { in Russia }\end{array}$ & Daniel Berkowitz and David N. DeJong & August 2000 \\
\hline $\begin{array}{l}\text { No. } 333 \text { Efficiency and Market Share in } \\
\text { Hungarian Corporate Sector }\end{array}$ & László Halpern and Gábor Körösi & July 2000 \\
\hline $\begin{array}{l}\text { No. } 332 \text { Search-Money-and-Barter Models of } \\
\text { Financial Stabilization }\end{array}$ & S.I. Boyarchenko and S.Z. Levendorskii & July 2000 \\
\hline $\begin{array}{l}\text { No. } 331 \text { Worker Training in a Restructuring } \\
\text { Economy: Evidence from the Russian } \\
\text { Transition }\end{array}$ & $\begin{array}{l}\text { Mark C. Berger, John S. Earle and Klara } \\
\text { Z. Sabirianova }\end{array}$ & August 2000 \\
\hline $\begin{array}{l}\text { No. 330 Economic Development in Palanpur } \\
\text { 1957-1993: A Sort of Growth }\end{array}$ & Peter Lanjouw & August 2000 \\
\hline $\begin{array}{l}\text { No. } 329 \text { Trust, Organizational Controls, } \\
\text { Knowledge Acquisition from the Foreign } \\
\text { Parents, and Performance in Vietnamese } \\
\text { International Joint Ventures }\end{array}$ & $\begin{array}{l}\text { Marjorie A. Lyles, Le Dang Doanh, and } \\
\text { Jeffrey Q. Barden }\end{array}$ & June 2000 \\
\hline $\begin{array}{l}\text { No. } 328 \text { Comparative Advertising in the } \\
\text { Global Marketplace: The Effects of Cultural } \\
\text { Orientation on Communication }\end{array}$ & $\begin{array}{l}\text { Zeynep Gürhan-Canli and Durairaj } \\
\text { Maheswaran }\end{array}$ & August 2000 \\
\hline $\begin{array}{l}\text { No. } 327 \text { Post Privatization Enterprise } \\
\text { Restructuring }\end{array}$ & Morris Bornstein & July 2000 \\
\hline No. 326 Who is Afraid of Political Instability? & Nauro F. Campos and Jeffrey B. Nugent & July 2000 \\
\hline $\begin{array}{l}\text { No. } 325 \text { Business Groups, the Financial } \\
\text { Market and Modernization }\end{array}$ & Raja Kali & June 2000 \\
\hline $\begin{array}{l}\text { No. } 324 \text { Restructuring with What Success? A } \\
\text { Case Study of Russian Firms }\end{array}$ & Susan Linz & July 2000 \\
\hline $\begin{array}{l}\text { No. } 323 \text { Priorities and Sequencing in } \\
\text { Privatization: Theory and Evidence from the } \\
\text { Czech Republic }\end{array}$ & $\begin{array}{l}\text { Nandini Gupta, John C. Ham and Jan } \\
\text { Svejnar }\end{array}$ & May 2000 \\
\hline $\begin{array}{l}\text { No. } 322 \text { Liquidity, Volatility, and Equity } \\
\text { Trading Costs Across Countries and Over } \\
\text { Time }\end{array}$ & $\begin{array}{l}\text { Ian Domowitz, Jack Glen and Ananth } \\
\text { Madhavan }\end{array}$ & March 2000 \\
\hline $\begin{array}{l}\text { No. } 321 \text { Equilibrium Wage Arrears: } \\
\text { Institutional Lock-In of Contractual Failure in } \\
\text { Russia }\end{array}$ & John S. Earle and Klara Z. Sabirianova & June 2000 \\
\hline $\begin{array}{l}\text { No. } 320 \text { Rethinking Marketing Programs for } \\
\text { Emerging Markets }\end{array}$ & Niraj Dawar and Amitava Chattopadhyay & June 2000 \\
\hline $\begin{array}{l}\text { No. } 319 \text { Public Finance and Low Equilibria in } \\
\text { Transition Economies; the Role of Institutions }\end{array}$ & Daniel Daianu and Radu Vranceanu & June 2000 \\
\hline
\end{tabular}


William Davidson Institute Working Paper 339

\begin{tabular}{|c|c|c|}
\hline $\begin{array}{l}\text { No. } 318 \text { Some Econometric Evidence on the } \\
\text { Effectiveness of Active Labour Market } \\
\text { Programmes in East Germany }\end{array}$ & Martin Eichler and Michael Lechner & June 2000 \\
\hline $\begin{array}{l}\text { No. } 317 \text { A Model of Russia's "Virtual } \\
\text { Economy" }\end{array}$ & R.E Ericson and B.W Ickes & May 2000 \\
\hline $\begin{array}{l}\text { No. } 316 \text { Financial Institutions, Financial } \\
\text { Contagion, and Financial Crises }\end{array}$ & Haizhou Huang and Chenggang Xu & March 2000 \\
\hline $\begin{array}{l}\text { No. } 315 \text { Privatization versus Regulation in } \\
\text { Developing Economies: The Case of West } \\
\text { African Banks }\end{array}$ & $\begin{array}{l}\text { Jean Paul Azam, Bruno Biais, and } \\
\text { Magueye Dia }\end{array}$ & February 2000 \\
\hline $\begin{array}{l}\text { No. } 314 \text { Is Life More Risky in the Open? } \\
\text { Household Risk-Coping and the Opening of } \\
\text { China's Labor Markets }\end{array}$ & John Giles & April 2000 \\
\hline $\begin{array}{l}\text { No. } 313 \text { Networks, Migration and Investment: } \\
\text { Insiders and Outsiders in Tirupur's } \\
\text { Production Cluster }\end{array}$ & Abhijit Banerjee and Kaivan Munshi & March 2000 \\
\hline $\begin{array}{l}\text { No. } 312 \text { Computational Analysis of the Impact } \\
\text { on India of the Uruguay Round and the } \\
\text { Forthcoming WTO Trade Negotiations }\end{array}$ & $\begin{array}{l}\text { Rajesh Chadha, Drusilla K. Brown, Alan } \\
\text { V. Deardorff and Robert M. Stern }\end{array}$ & March 2000 \\
\hline $\begin{array}{l}\text { No. } 311 \text { Subsidized Jobs for Unemployed } \\
\text { Workers in Slovakia }\end{array}$ & Jan. C. van Ours & May 2000 \\
\hline $\begin{array}{l}\text { No. } 310 \text { Determinants of Managerial Pay in } \\
\text { the Czech Republic }\end{array}$ & $\begin{array}{l}\text { Tor Eriksson, Jaromir Gottvald and Pavel } \\
\text { Mrazek }\end{array}$ & May 2000 \\
\hline $\begin{array}{l}\text { No. } 309 \text { The Great Human Capital } \\
\text { Reallocation: An Empirical Analysis of } \\
\text { Occupational Mobility in Transitional Russia }\end{array}$ & Klara Z. Sabirianova & May 2000 \\
\hline $\begin{array}{l}\text { No. } 308 \text { Economic Development, Legality, and } \\
\text { the Transplant Effect }\end{array}$ & $\begin{array}{l}\text { Daniel Berkowitz, Katharina Pistor, and } \\
\text { Jean-Francois Richard }\end{array}$ & February 2000 \\
\hline $\begin{array}{l}\text { No. } 307 \text { Community Participation, Teacher } \\
\text { Effort, and Educational Outcome: The Case of } \\
\text { El Salvador's EDUCO Program }\end{array}$ & Yasuyuki Sawada & November 1999 \\
\hline $\begin{array}{l}\text { No. } 306 \text { Gender Wage Gap and Segregation } \\
\text { in Late Transition }\end{array}$ & Stepan Jurajda & May 2000 \\
\hline $\begin{array}{l}\text { No. } 305 \text { The Gender Pay Gap in the } \\
\text { Transition from Communism: Some Empirical } \\
\text { Evidence }\end{array}$ & Andrew Newell and Barry Reilly & May 2000 \\
\hline $\begin{array}{l}\text { No. } 304 \text { Post-Unification Wage Growth in } \\
\text { East Germany }\end{array}$ & Jennifer Hunt & November 1998 \\
\hline $\begin{array}{l}\text { No. } 303 \text { How Does Privatization Affect } \\
\text { Workers? The Case of the Russian Mass } \\
\text { Privatization Program }\end{array}$ & Elizabeth Brainerd & May 2000 \\
\hline $\begin{array}{l}\text { No. } 302 \text { Liability for Past Environmental } \\
\text { Contamination and Privatization }\end{array}$ & Dietrich Earnhart & March 2000 \\
\hline No. 301 Varieties, Jobs and EU Enlargement & Tito Boeri and Joaquim Oliveira Martins & May 2000 \\
\hline No. 300 Employer Size Effects in Russia & Todd Idson & April 2000 \\
\hline $\begin{array}{l}\text { No. } 299 \text { Information Complements, } \\
\text { Substitutes, and Strategic Product Design }\end{array}$ & $\begin{array}{l}\text { Geoffrey G. Parker and Marshall W. Van } \\
\text { Alstyne }\end{array}$ & March 2000 \\
\hline $\begin{array}{l}\text { No. } 298 \text { Markets, Human Capital, and } \\
\text { Inequality: Evidence from Rural China }\end{array}$ & $\begin{array}{l}\text { Dwayne Benjamin, Loren Brandt, Paul } \\
\text { Glewwe, and Li Guo }\end{array}$ & May 2000 \\
\hline $\begin{array}{l}\text { No. } 297 \text { Corporate Governance in the Asian } \\
\text { Financial Crisis }\end{array}$ & $\begin{array}{l}\text { Simon Johnson, Peter Boone, Alasdair } \\
\text { Breach, and Eric Friedman }\end{array}$ & November 1999 \\
\hline $\begin{array}{l}\text { No. } 296 \text { Competition and Firm Performance: } \\
\text { Lessons from Russia }\end{array}$ & J. David Brown and John S. Earle & March 2000 \\
\hline $\begin{array}{l}\text { No. } 295 \text { Wage Determination in Russia: } A n \\
\text { Econometric Investigation }\end{array}$ & Peter J. Luke and Mark E. Schaffer & March 2000 \\
\hline $\begin{array}{l}\text { No. 294: Can Banks Promote Enterprise } \\
\text { Restructuring?: Evidence From a Polish }\end{array}$ & John P. Bonin and Bozena Leven & March 2000 \\
\hline
\end{tabular}




\begin{tabular}{|c|c|c|}
\hline Bank's Experience & & \\
\hline $\begin{array}{l}\text { No. 293: Why do Governments Sell Privatised } \\
\text { Companies Abroad? }\end{array}$ & $\begin{array}{l}\text { Bernardo Bortolotti, Marcella Fantini and } \\
\text { Carlo Scarpa }\end{array}$ & March 2000 \\
\hline $\begin{array}{l}\text { No. 292: Going Public in Poland: Case-by- } \\
\text { Case Privatizations, Mass Privatization and } \\
\text { Private Sector Initial Public Offerings }\end{array}$ & Wolfgang Aussenegg & December 1999 \\
\hline $\begin{array}{l}\text { No. 291: Institutional Technology and the } \\
\text { Chains of Trust: Capital Markets and } \\
\text { Privatization in Russia and the Czech } \\
\text { Republic }\end{array}$ & Bruce Kogut and Andrew Spicer & March 1999 \\
\hline $\begin{array}{l}\text { No. 290: Banking Crises and Bank Rescues: } \\
\text { The Effect of Reputation }\end{array}$ & Jenny Corbett and Janet Mitchell & January 2000 \\
\hline $\begin{array}{l}\text { No. 289: Do Active Labor Market Policies } \\
\text { Help Unemployed Workers to Find and Keep } \\
\text { Regular Jobs? }\end{array}$ & Jan C. van Ours & February 2000 \\
\hline $\begin{array}{l}\text { No. 288: Consumption Patterns of the New } \\
\text { Elite in Zimbabwe }\end{array}$ & Russell Belk & February 2000 \\
\hline $\begin{array}{l}\text { No. 287: Barter in Transition Economies: } \\
\text { Competing Explanations Confront Ukranian } \\
\text { Data }\end{array}$ & $\begin{array}{l}\text { Dalia Marin, Daniel Kaufmann and } \\
\text { Bogdan Gorochowskij }\end{array}$ & January 2000 \\
\hline $\begin{array}{l}\text { No. 286: The Quest for Pension Reform: } \\
\text { Poland's Security through Diversity }\end{array}$ & Marek Góra and Michael Rutkowski & January 2000 \\
\hline $\begin{array}{l}\text { No. 285: Disorganization and Financial } \\
\text { Collapse }\end{array}$ & Dalia Marin and Monika Schnitzer & October 1999 \\
\hline $\begin{array}{l}\text { No. 284: Coordinating Changes in M-form } \\
\text { and U-form Organizations }\end{array}$ & $\begin{array}{l}\text { Yingyi Qian, Gérard Roland and } \\
\text { Chenggang } X u\end{array}$ & May 1999 \\
\hline $\begin{array}{l}\text { No. 283: Why Russian Workers Do Not Move: } \\
\text { Attachment of Workers Through In-Kind } \\
\text { Payments }\end{array}$ & Guido Friebel and Sergei Guriev & October 1999 \\
\hline $\begin{array}{l}\text { No. 282: Lessons From Fiascos in Russian } \\
\text { Corporate Governance }\end{array}$ & Merritt B. Fox and Michael A. Heller & October 1999 \\
\hline $\begin{array}{l}\text { No. 281: Income Distribution and Price } \\
\text { Controls: Targeting a Social Safety Net } \\
\text { During Economic Transition }\end{array}$ & Michael Alexeev and James Leitzel & March 1999 \\
\hline $\begin{array}{l}\text { No. 280: Starting Positions, Reform Speed, } \\
\text { and Economic Outcomes in Transitioning } \\
\text { Economies }\end{array}$ & William Hallagan and Zhang Jun & January 2000 \\
\hline No. 279: The Value of Prominent Directors & Yoshiro Miwa \& J. Mark Ramseyer & October 1999 \\
\hline No. 278: The System Paradigm & János Kornai & April 1998 \\
\hline $\begin{array}{l}\text { No. 277: The Developmental Consequences of } \\
\text { Foreign Direct Investment in the Transition } \\
\text { from Socialism to Capitalism: The } \\
\text { Performance of Foreign Owned Firms in } \\
\text { Hungary }\end{array}$ & Lawrence Peter King & September 1999 \\
\hline $\begin{array}{l}\text { No. 276: Stability and Disorder: An } \\
\text { Evolutionary Analysis of Russia's Virtual } \\
\text { Economy }\end{array}$ & Clifford Gaddy and Barry W. Ickes & November 1999 \\
\hline $\begin{array}{l}\text { No. 275: Limiting Government Predation } \\
\text { Through Anonymous Banking: A Theory with } \\
\text { Evidence from China. }\end{array}$ & $\begin{array}{l}\text { Chong-En Bai, David D. Li, Yingyi Qian } \\
\text { and Yijiang Wang }\end{array}$ & July 1999 \\
\hline No. 274: Transition with Labour Supply & Tito Boeri & December 1999 \\
\hline $\begin{array}{l}\text { No. 273: Sectoral Restructuring and Labor } \\
\text { Mobility: A Comparative Look at the Czech } \\
\text { Republic }\end{array}$ & Vit Sorm and Katherine Terrell & November 1999 \\
\hline $\begin{array}{l}\text { No. 272: Published in: Journal of } \\
\text { Comparative Economics "Returns to Human } \\
\text { Capital Under the Communist Wage Grid and }\end{array}$ & $\begin{array}{l}\text { Daniel Munich, Jan Svejnar and Katherine } \\
\text { Terrell }\end{array}$ & October 1999 \\
\hline
\end{tabular}




\begin{tabular}{|c|c|c|}
\hline $\begin{array}{l}\text { During the Transition to a Market Economy" } \\
\text { Vol. 27, pp. 33-60 } 1999 .\end{array}$ & & \\
\hline $\begin{array}{l}\text { No. 271: Barter in Russia: Liquidity Shortage } \\
\text { Versus Lack of Restructuring }\end{array}$ & Sophie Brana and Mathilde Maurel & June 1999 \\
\hline $\begin{array}{l}\text { No. 270: Tests for Efficient Financial } \\
\text { Intermediation with Application to China }\end{array}$ & Albert Park and Kaja Sehrt & March 1999 \\
\hline $\begin{array}{l}\text { No. 269a: Russian Privatization and } \\
\text { Corporate Governance: What Went Wrong? }\end{array}$ & $\begin{array}{l}\text { Bernard Black, Reinier Kraakman and } \\
\text { Anna Tarassova }\end{array}$ & May 2000 \\
\hline $\begin{array}{l}\text { No. 269: Russian Privatization and Corporate } \\
\text { Governance: What Went Wrong? }\end{array}$ & $\begin{array}{l}\text { Bernard Black, Reinier Kraakman and } \\
\text { Anna Tarassova }\end{array}$ & September 1999 \\
\hline $\begin{array}{l}\text { No. 268: Are Russians Really Ready for } \\
\text { Capitalism? }\end{array}$ & Susan Linz & September 1999 \\
\hline $\begin{array}{l}\text { No. 267: Do Stock Markets Promote } \\
\text { Economic Growth? }\end{array}$ & $\begin{array}{l}\text { Randall K. Filer, Jan Hanousek and Nauro } \\
\text { Campos }\end{array}$ & September 1999 \\
\hline $\begin{array}{l}\text { No. 266: Objectivity, Proximity and } \\
\text { Adaptability in Corporate Governance }\end{array}$ & Arnoud W.A Boot and Jonathan R. Macey & September 1999 \\
\hline $\begin{array}{l}\text { No. 265: When the Future is not What it Used } \\
\text { to Be: Lessons from the Western European } \\
\text { Experience to Forecasting Education and } \\
\text { Training in Transitional Economies }\end{array}$ & $\begin{array}{l}\text { Nauro F. Campos, Gerard Hughes, Stepan } \\
\text { Jurajda, and Daniel Munich }\end{array}$ & September 1999 \\
\hline $\begin{array}{l}\text { No. 264: The Institutional Foundation of } \\
\text { Foreign-Invested Enterprises (FIEs) in China }\end{array}$ & Yasheng Huang & September 1999 \\
\hline $\begin{array}{l}\text { No. 263: The Changing Corporate } \\
\text { Governance Paradigm: Implications for } \\
\text { Transition and Developing Countries }\end{array}$ & $\begin{array}{l}\text { Erik Berglof and Ernst-Ludwig von } \\
\text { Thadden }\end{array}$ & June 1999 \\
\hline No. 262: Law Enforcement and Transition & Gerard Roland and Thierry Verdier & May 1999 \\
\hline $\begin{array}{l}\text { No. 261: Soft Budget Constraints, Pecuniary } \\
\text { Externality, and the Dual Track System }\end{array}$ & Jiahua Che & June 2000 \\
\hline $\begin{array}{l}\text { No. 260: Missing Market in Labor Quality: } \\
\text { The Role of Quality Markets in Transition }\end{array}$ & Gary H. Jefferson & July 1999 \\
\hline $\begin{array}{l}\text { No. 259: Do Corporate Global Environmental } \\
\text { Standards in Emerging Markets Create or } \\
\text { Destroy Market Value }\end{array}$ & $\begin{array}{l}\text { Glen Dowell, Stuart Hart and Bernard } \\
\text { Yeung }\end{array}$ & June 1999 \\
\hline $\begin{array}{l}\text { No. 258: Public Training and Outflows from } \\
\text { Unemployment }\end{array}$ & Patrick A. Puhani & June 1999 \\
\hline $\begin{array}{l}\text { No. 257: Ownership Versus Environment: } \\
\text { Why are Public Sector Firms Inefficient? }\end{array}$ & Ann P. Bartel and Ann E. Harrison & June 1999 \\
\hline $\begin{array}{l}\text { No. 256: Taxation and Evasion in the } \\
\text { Presence of Exortion by Organized Crime }\end{array}$ & $\begin{array}{l}\text { Michael Alexeev, Eckhard Janeba and } \\
\text { Stefan Osborne }\end{array}$ & November 1999 \\
\hline $\begin{array}{l}\text { No. 255: Revisiting Hungary's Bankruptcy } \\
\text { Episode }\end{array}$ & John P. Bonin and Mark E. Schaffer & September 1999 \\
\hline $\begin{array}{l}\text { No. 254: FDI in Emerging Markets: A Home- } \\
\text { Country View }\end{array}$ & Marina v.N Whitman & June 1999 \\
\hline $\begin{array}{l}\text { No. 253: The Asian Financial Crisis: What } \\
\text { Happened, and What is to be Done }\end{array}$ & Jeffrey D. Sachs and Wing Thye Woo & January 1999 \\
\hline $\begin{array}{l}\text { No. 252: Organizational Law as Asset } \\
\text { Partitioning }\end{array}$ & Henry Hansmann and Reinier Kraakman & September 1999 \\
\hline $\begin{array}{l}\text { No. 251: Consumer Behavior Research in } \\
\text { Emerging Consumer Markets: the Case of the } \\
\text { Optimum Stimulation Level in South Africa }\end{array}$ & $\begin{array}{l}\text { Jan-Benedict E. M. Steenkamp and Steven } \\
\text { M. Burgess }\end{array}$ & September 1999 \\
\hline $\begin{array}{l}\text { No. 250: Property Rights Formation and the } \\
\text { Organization of Exchange and Production in } \\
\text { Rural China }\end{array}$ & $\begin{array}{l}\text { Matthew A. Turner, Loren Brandt, and } \\
\text { Scott Rozelle }\end{array}$ & July 1998 \\
\hline $\begin{array}{l}\text { No. 249: Impacts of the Indonesian Economic } \\
\text { Crisis: Price Changes and the Poor }\end{array}$ & $\begin{array}{l}\text { James Levinsohn, Steven Berry, and Jed } \\
\text { Friedman }\end{array}$ & June 1999 \\
\hline $\begin{array}{l}\text { No. 248: Internal Barriers in the Transition of } \\
\text { Enterprises from Central Plan to Market }\end{array}$ & Charalambos Vlachoutsicos & July 1999 \\
\hline
\end{tabular}




\begin{tabular}{|c|c|c|}
\hline $\begin{array}{l}\text { No. 247: Spillovers from Multinationals in } \\
\text { Developing Countries: the Mechanisms at } \\
\text { Work }\end{array}$ & Richard E. Caves & June 1999 \\
\hline $\begin{array}{l}\text { No. 246: Dynamism and Inertia on the } \\
\text { Russian Labour Market: A Model of } \\
\text { Segmentation }\end{array}$ & $\begin{array}{l}\text { Irena Grosfeld, Claudia Senik-Leygonie, } \\
\text { Thierry Verdier, Stanislav Kolenikov and } \\
\text { Elena Paltseva }\end{array}$ & May 1999 \\
\hline $\begin{array}{l}\text { No. 245: Lessons from Bank Privatization in } \\
\text { Central Europe }\end{array}$ & John Bonin and Paul Wachtel & May 1999 \\
\hline $\begin{array}{l}\text { No. 244: Nominal-Real Tradeoffs and the } \\
\text { Effects of Monetary Policy: the Romanian } \\
\text { Experience }\end{array}$ & Christian Popa & December 1998 \\
\hline $\begin{array}{l}\text { No. 243: Privatization, Political Risk and } \\
\text { Stock Market Development in Emerging } \\
\text { Economies }\end{array}$ & Enrico C. Perotti and Pieter van Oijen & March 1999 \\
\hline $\begin{array}{l}\text { No. 242: Investment Financing in Russian } \\
\text { Financial-Industrial Groups }\end{array}$ & Enrico C. Perotti and Stanislav Gelfer & October 1998 \\
\hline $\begin{array}{l}\text { No. 241: Can governments maintain hard } \\
\text { budget constraints? Bank lending and } \\
\text { financial isolation in Romania }\end{array}$ & $\begin{array}{l}\text { Octavian Carare, Constantijn Claessens, } \\
\text { Enrico C. Perotti }\end{array}$ & January 1999 \\
\hline $\begin{array}{l}\text { No. 240: Democratic Institutions and } \\
\text { Economic Reform: the Polish Case }\end{array}$ & $\begin{array}{l}\text { John E. Jackson, Jacek Klich, and } \\
\text { Krystyna Poznanska }\end{array}$ & April 1998 \\
\hline $\begin{array}{l}\text { No. 239: A Longitudinal Study of IJV } \\
\text { Performance in Eastern Europe }\end{array}$ & Keith D. Brouthers and Gary Bamossy & June 1999 \\
\hline $\begin{array}{l}\text { No. 238: Published in: Journal of Business } \\
\text { Venturing, "Firm Creation and Economic } \\
\text { Transitions" Vol. 14, Iss. 5, } 6 \text { Sep/Nov 1999, } \\
\text { pp. 427-450. }\end{array}$ & $\begin{array}{l}\text { John E. Jackson, Jacek Klich, Krystyna } \\
\text { Poznanska }\end{array}$ & July 1998 \\
\hline $\begin{array}{l}\text { No. 237: Analysis of Entrepreneurial Attitudes } \\
\text { in Poland }\end{array}$ & $\begin{array}{l}\text { John E. Jackson and Aleksander S. } \\
\text { Marcinkowski }\end{array}$ & March 1997 \\
\hline $\begin{array}{l}\text { No. 236: Investment and Finance in De Novo } \\
\text { Private Firms: Empirical Results from the } \\
\text { Czech Republic, Hungary, and Poland }\end{array}$ & $\begin{array}{l}\text { Andrzej Bratkowski, Irena Grosfeld, Jacek } \\
\text { Rostowski }\end{array}$ & April 1999 \\
\hline $\begin{array}{l}\text { No. 235: Does a Soft Macroeconomic } \\
\text { Environment Induce Restructuring on the } \\
\text { Microeconomic Level during the Transition } \\
\text { Period? Evidence from Investment Behavior } \\
\text { of Czech Enterprises }\end{array}$ & Lubomír Lizal & June 1999 \\
\hline $\begin{array}{l}\text { No. 234: Banking Reform in China: Gradually } \\
\text { Strengthening Pillar or Fragile Reed? }\end{array}$ & John Bonin & June 1999 \\
\hline $\begin{array}{l}\text { No. 233: Theories of Soft Budget Constraints } \\
\text { and the Analysis of Banking Crises }\end{array}$ & Janet Mitchell & March 1999 \\
\hline $\begin{array}{l}\text { No. 232: Unemployment Risk, Precautionary } \\
\text { Savings, and Moonlighting in Russia }\end{array}$ & $\begin{array}{l}\text { Alessandra Guariglia and Byung-Yeon } \\
\text { Kim }\end{array}$ & June 1999 \\
\hline $\begin{array}{l}\text { No. 231: Investing in Turbulent Times: The } \\
\text { Investment Behavior of Polish Firms in the } \\
\text { Transition }\end{array}$ & $\begin{array}{l}\text { Josef C. Brada, Arthur E. King, and Chia- } \\
\text { Ying Ma }\end{array}$ & April 1999 \\
\hline $\begin{array}{l}\text { No. 230: The End of Moderate Inflation in } \\
\text { Three Transition Economies? }\end{array}$ & Josef C. Brada and Ali M. Kutan & April 1999 \\
\hline $\begin{array}{l}\text { No. 229: Back to the Future: The Growth } \\
\text { Prospects of Transition Economies } \\
\text { Reconsidered }\end{array}$ & Nauro F. Campos & April 1999 \\
\hline $\begin{array}{l}\text { No. 228: The Enterprise Isolation Program in } \\
\text { Russia }\end{array}$ & Simeon Djankov & April 1999 \\
\hline $\begin{array}{l}\text { No. 227: Published in: Journal of } \\
\text { Comparative Economics, “Ownership } \\
\text { Concentration and Corporate Performance in } \\
\text { the Czech Republic” 27(3), September 1999, } \\
\text { pp. 498-513. }\end{array}$ & Stijn Claessens and Simeon Djankov & April 1999 \\
\hline
\end{tabular}




\begin{tabular}{|c|c|c|}
\hline $\begin{array}{l}\text { No. 226: Unemployment Benefit Entitlement } \\
\text { and Training Effects in Poland during } \\
\text { Transition }\end{array}$ & Patrick A. Puhani & March 1999 \\
\hline $\begin{array}{l}\text { No. 225: Transition at Whirlpool-Tatramat: } \\
\text { Case Studies }\end{array}$ & Hans Brechbuhl and Sonia Ferencikova & March 1999 \\
\hline $\begin{array}{l}\text { No. 224: Measuring Progress in Transition } \\
\text { and Towards EU Accession: A Comparison of } \\
\text { Manufacturing Firms in Poland, Romania, } \\
\text { and Spain }\end{array}$ & $\begin{array}{l}\text { Wendy Carlin, Saul Estrin, and Mark } \\
\text { Schaffer }\end{array}$ & March 1999 \\
\hline $\begin{array}{l}\text { No. 223: Product Market Competition in } \\
\text { Transition Economies: Increasing Varieties } \\
\text { and Consumer Loyalty }\end{array}$ & Mitsutoshi M. Adachi & March 1999 \\
\hline $\begin{array}{l}\text { No. 222: Opaque Markets and Rapid Growth: } \\
\text { the Superiority of Bank-Centered Financial } \\
\text { Systems for Developing Nations }\end{array}$ & Rodney Wallace & July 1999 \\
\hline $\begin{array}{l}\text { No. 221: Technology Spillovers through } \\
\text { Foreign Direct Investment }\end{array}$ & Yuko Kinoshita & January 1999 \\
\hline $\begin{array}{l}\text { No. 220: Managerial, Expertise and Team } \\
\text { Centered Forms of Organizing: A Cross- } \\
\text { Cultural Exploration of Independence in } \\
\text { Engineering Work }\end{array}$ & Leslie Perlow & January 1999 \\
\hline $\begin{array}{l}\text { No. 219: Household Structure and Labor } \\
\text { Demand in Agriculture: Testing for } \\
\text { Separability in Rural China }\end{array}$ & Audra J. Bowlus and Terry Sicular & January 1999 \\
\hline $\begin{array}{l}\text { No. 218: Competing Strategies of FDI and } \\
\text { Technology Transfer to China: American and } \\
\text { Japanese Firms }\end{array}$ & W. Mark Fruin and Penelope Prime & January 1999 \\
\hline $\begin{array}{l}\text { No. } 217 \text { Published in: Journal of } \\
\text { Comparative Economics, "Returns to } \\
\text { Mobility in the Transition to a Market } \\
\text { Economy" Vol. 27, No. 1, March 1999, pp. 4- }\end{array}$ & Tito Boeri and Christopher J. Flinn & January 1999 \\
\hline $\begin{array}{l}\text { No. } 216 \text { Published in: Journal of } \\
\text { Comparative Economics, “Labor Market } \\
\text { Policies and Unemployment in the Czech } \\
\text { Republic." Vol. 27, No. 1, March 1999, pp. } \\
\text { 33-60. }\end{array}$ & Katherine Terrell and Vit Sorm & November 1998 \\
\hline $\begin{array}{l}\text { No. } 215 \text { Published in: Journal of } \\
\text { Comparative Economics, “Active Labor } \\
\text { Market Policies in Poland: Human Capital } \\
\text { Enhancement, Stigmatization or Benefit } \\
\text { Churning?” Vol. 27, No. 1, March 1999, pp. } \\
\text { 61- }\end{array}$ & $\begin{array}{l}\text { Jochen Kluve, Hartmut Lehmann, and } \\
\text { Christoph M. Schmidt }\end{array}$ & December 1998 \\
\hline $\begin{array}{l}\text { No. } 214 \text { Published in: Journal of } \\
\text { Comparative Economics, “Does the } \\
\text { Slovenian Public Work Program Increase } \\
\text { Participants' Chances to Find a Job?" Vol. } \\
\text { 27, No.1, March 1999, pp. 113- }\end{array}$ & Milan Vodopivec & December 1998 \\
\hline $\begin{array}{l}\text { No. } 213 \text { Published in: Journal of } \\
\text { Comparative Economics, "Effects of Active } \\
\text { Labor Market Programs on the Transition } \\
\text { Rate from Unemployment into Regular Jobs in } \\
\text { the Slovak Republic." Vol. 27, No. 1, March } \\
\text { 1999, pp. 90- }\end{array}$ & Martina Lubyova and Jan C. van Ours & December 1998 \\
\hline $\begin{array}{l}\text { No. 212: The Marketing System in Bulgarian } \\
\text { Livestock Production - The Present State and } \\
\text { Evolutionary Processes During the Period of } \\
\text { Economic Transition }\end{array}$ & Yordan Staykov, Team Leader & October 1998 \\
\hline No. 211: Bankruptcy Experience in Hungary & Janet Mitchell & October 1998 \\
\hline
\end{tabular}


William Davidson Institute Working Paper 339

\begin{tabular}{|c|c|c|}
\hline and the Czech Republic & & \\
\hline $\begin{array}{l}\text { No 210: Values, Optimum Stimulation Levels } \\
\text { and Brand Loyalty: New Scales in New } \\
\text { Populations }\end{array}$ & Steven M. Burgess and Mari Harris & September 1998 \\
\hline $\begin{array}{l}\text { No. 209: Inherited Wealth, Corporate Control } \\
\text { and Economic Growth }\end{array}$ & $\begin{array}{l}\text { Randall K. Morck, David A. Stangeland, } \\
\text { and Bernard Yeung }\end{array}$ & September 1998 \\
\hline $\begin{array}{l}\text { No. 208: A Cultural Analysis of Homosocial } \\
\text { Reproduction and Contesting Claims to } \\
\text { Competence in Transitional Firms }\end{array}$ & Michael D. Kennedy & July 1998 \\
\hline $\begin{array}{l}\text { No. 207: From Survival to Success: The } \\
\text { Journey of Corporate Transformation at } \\
\text { Haier. Forthcoming in Teaching the } \\
\text { Dinosaurs to Dance: Organizational Change } \\
\text { in Transition Economies ed. Daniel Denison. }\end{array}$ & Arthur Yeung and Kenneth DeWoskin & July 1998 \\
\hline $\begin{array}{l}\text { No. 206: Why Do People Work If They Are } \\
\text { Not Paid? An Example from Eastern Europe. } \\
\text { Forthcoming in Teaching the Dinosaurs to } \\
\text { Dance: Organizational Change in Transition } \\
\text { Economies ed. Daniel Denison. }\end{array}$ & Irina L. Zinovieva & May 1998 \\
\hline $\begin{array}{l}\text { No. 205: Firm Ownership and Work } \\
\text { Motivation in Bulgaria and Hungary: An } \\
\text { Empirical Study of the Transition in the Mid- } \\
\text { 1990s. Forthcoming in Teaching the } \\
\text { Dinosaurs to Dance: Organizational Change } \\
\text { in Transition Economies ed. Daniel Denison. }\end{array}$ & $\begin{array}{l}\text { Robert A. Roe, Irina L. Zinovieva, } \\
\text { Elizabeth Dienes, and Laurens A.ten Horn }\end{array}$ & May 1998 \\
\hline $\begin{array}{l}\text { No. 204: Human Resource Management in the } \\
\text { Restructuring of Chinese Joint Ventures. } \\
\text { Forthcoming in Teaching the Dinosaurs to } \\
\text { Dance: Organizational Change in Transition } \\
\text { Economies ed. Daniel Denison. }\end{array}$ & Nandani Lynton & April 1998 \\
\hline $\begin{array}{l}\text { No. 203: Emergent Compensation Strategies } \\
\text { in Post-Socialist Poland: Understanding the } \\
\text { Cognitive Underpinnings of Management } \\
\text { Practices in a Transition Economy. } \\
\text { Forthcoming in Teaching the Dinosaurs to } \\
\text { Dance: Organizational Change in Transition } \\
\text { Economies ed. Daniel Denison. }\end{array}$ & Marc Weinstein & March 1998 \\
\hline $\begin{array}{l}\text { No. 202: Corporate Transformation and } \\
\text { Organizational Learning: The People's } \\
\text { Republic of China. Forthcoming in Teaching } \\
\text { the Dinosaurs to Dance: Organizational } \\
\text { Change in Transition Economies ed. Daniel } \\
\text { Denison. }\end{array}$ & Meinolf Dierkes and Zhang Xinhua & March 1998 \\
\hline $\begin{array}{l}\text { No. 201: Foreign Direct Investment as a } \\
\text { Factor of Change: The Case of Slovakia. } \\
\text { Forthcoming in Teaching the Dinosaurs to } \\
\text { Dance: Organizational Change in Transition } \\
\text { Economies ed. Daniel Denison. }\end{array}$ & Sonia Ferencikova & February 1998 \\
\hline $\begin{array}{l}\text { No. 200: Radical versus Incremental Change: } \\
\text { The Role of Capabilities, Competition, and } \\
\text { Leaders. Forthcoming in Teaching the } \\
\text { Dinosaurs to Dance: Organizational Change } \\
\text { in Transition Economies ed. Daniel Denison. }\end{array}$ & Karen L. Newman & February 1998 \\
\hline $\begin{array}{l}\text { No. 199: The Emergence of Market Practices } \\
\text { in China's Economic Transition: Price Setting } \\
\text { Practices in Shanghai's Industrial Firms. } \\
\text { Forthcoming in Teaching the Dinosaurs to } \\
\text { Dance: Organizational Change in Transition }\end{array}$ & Douglas Guthrie & February 1998 \\
\hline
\end{tabular}




\begin{tabular}{|c|c|c|}
\hline Economies ed. Daniel Denison. & & \\
\hline $\begin{array}{l}\text { No. 198: The Application of Change } \\
\text { Management Methods at Business } \\
\text { Organizations Operating in Hungary: } \\
\text { Challenges in the Business and Cultural } \\
\text { Environment and First Practical Experiences. } \\
\text { Forthcoming in Teaching the Dinosaurs to } \\
\text { Dance: Organizational Change in Transition } \\
\text { Economies ed. Daniel Denison. }\end{array}$ & Dr. János Fehér & January 1998 \\
\hline $\begin{array}{l}\text { No. 197: Organizational Changes in Russian } \\
\text { Industrial Enterprises: Mutation of Decision- } \\
\text { Making Structures and Transformations of } \\
\text { Ownership. Forthcoming in Teaching the } \\
\text { Dinosaurs to Dance: Organizational Change } \\
\text { in Transition Economies ed. Daniel Denison. }\end{array}$ & Igor B. Gurkov & January 1998 \\
\hline $\begin{array}{l}\text { No. 196: Understanding and Managing } \\
\text { Challenges to the Romanian Companies } \\
\text { during Transition. Forthcoming in Teaching } \\
\text { the Dinosaurs to Dance: Organizational } \\
\text { Change in Transition Economies ed. Daniel } \\
\text { Denison. }\end{array}$ & Dan Candea and Rodica M. Candea & January 1998 \\
\hline $\begin{array}{l}\text { No. 195: Insider Lending and Economic } \\
\text { Transition: The Structure, Function, and } \\
\text { Performance Impact of Finance Companies in } \\
\text { Chinese Business Groups. Forthcoming in } \\
\text { Teaching the Dinosaurs to Dance: } \\
\text { Organizational Change in Transition } \\
\text { Economies ed. Daniel Denison. }\end{array}$ & Lisa A. Keister & December 1997 \\
\hline $\begin{array}{l}\text { No. 194: Japanese Investment in Transitional } \\
\text { Economies: Characteristics and Performance. } \\
\text { Forthcoming in Teaching the Dinosaurs to } \\
\text { Dance: Organizational Change in Transition } \\
\text { Economies ed. Daniel Denison. }\end{array}$ & Paul W. Beamish and Andrew Delios & November 1997 \\
\hline $\begin{array}{l}\text { No. 193: Building Successful Companies in } \\
\text { Transition Economies. Forthcoming in } \\
\text { Teaching the Dinosaurs to Dance: } \\
\text { Organizational Change in Transition } \\
\text { Economies ed. Daniel Denison. }\end{array}$ & Dr. Ivan Perlaki & January 1998 \\
\hline $\begin{array}{l}\text { No. 192: Russian Communitariansim: An } \\
\text { Invisible Fist in the Transformation Process of } \\
\text { Russia. Forthcoming in Teaching the } \\
\text { Dinosaurs to Dance: Organizational Change } \\
\text { in Transition Economies ed. Daniel Denison. }\end{array}$ & Charalambos Vlachoutsicos & July 1998 \\
\hline No. 191: Teaching the Dinosaurs to Dance & Michal Cakrt & September 1997 \\
\hline $\begin{array}{l}\text { No. 190: Strategic Restructuring: Making } \\
\text { Capitalism in Post-Communist Eastern } \\
\text { Europe. Forthcoming in Teaching the } \\
\text { Dinosaurs to Dance: Organizational Change } \\
\text { in Transition Economies ed. Daniel Denison. }\end{array}$ & Lawrence P. King & September 1997 \\
\hline $\begin{array}{l}\text { No. 189: Published in: Regional Science and } \\
\text { Urban Economics, “Russia's Internal } \\
\text { Border”, } 29 \text { (5), September } 1999 .\end{array}$ & Daniel Berkowitz and David N. DeJong & July 1998 \\
\hline $\begin{array}{l}\text { No. 187: Corporate Structure and } \\
\text { Performance in Hungary }\end{array}$ & László Halpern and Gábor Kórsöi & July 1998 \\
\hline $\begin{array}{l}\text { No. 186: Performance of Czech Companies by } \\
\text { Ownership Structure }\end{array}$ & Andrew Weiss and Georgiy Nikitin & June 1998 \\
\hline $\begin{array}{l}\text { No. 185: Firm Performance in Bulgaria and } \\
\text { Estonia: The effects of competitive pressure, }\end{array}$ & Jozef Konings & July 1998 \\
\hline
\end{tabular}




\begin{tabular}{|c|c|c|}
\hline financial pressure and disorganisation & & \\
\hline $\begin{array}{l}\text { No. 184: Investment and Wages during the } \\
\text { Transition: Evidence from Slovene Firms }\end{array}$ & Janez Prasnikar and Jan Svejnar & July 1998 \\
\hline $\begin{array}{l}\text { No. 183: Investment Portfolio under Soft } \\
\text { Budget: Implications for Growth, Volatility } \\
\text { and Savings }\end{array}$ & Chongen Bai and Yijiang Wang & July 1998 \\
\hline $\begin{array}{l}\text { No. 181: Delegation and Delay in Bank } \\
\text { Privatization }\end{array}$ & Loránd Ambrus-Lakatos and Ulrich Hege & July 1998 \\
\hline $\begin{array}{l}\text { No. 180: Financing Mechanisms and R\&D } \\
\text { Investment }\end{array}$ & Haizhou Huang and Chenggang Xu & July 1998 \\
\hline $\begin{array}{l}\text { No. 179: Organizational Culture and } \\
\text { Effectiveness: The Case of Foreign Firms in } \\
\text { Russia }\end{array}$ & Carl F. Fey and Daniel R. Denison & January 1999 \\
\hline $\begin{array}{l}\text { No. 178: Output and Unemployment } \\
\text { Dynamics in Transition }\end{array}$ & Vivek H. Dehejia and Douglas W. Dwyer & January 1998 \\
\hline $\begin{array}{l}\text { No. 177: Published in: Economics of } \\
\text { Transition,, "Bureaucracies in the Russian } \\
\text { Voucher Privatization" Vol. 8, No. 1, 2000, } \\
\text { pp. 37-57. }\end{array}$ & Guido Friebel & June 1998 \\
\hline $\begin{array}{l}\text { No. 176: Chronic Moderate Inflation in } \\
\text { Transition: The Tale of Hungary }\end{array}$ & János Vincze & June 1998 \\
\hline $\begin{array}{l}\text { No. 175: Privatisation and Market Structure } \\
\text { in a Transition Economy }\end{array}$ & John Bennett and James Maw & June 1998 \\
\hline $\begin{array}{l}\text { No. 174: Ownership and Managerial } \\
\text { Competition: Employee, Customer, or Outside } \\
\text { Ownership }\end{array}$ & Patrick Bolton and Chenggang Xu & June 1998 \\
\hline $\begin{array}{l}\text { No. 173: Intragovernment Procurement of } \\
\text { Local Public Good: A Theory of } \\
\text { Decentralization in Nondemocratic } \\
\text { Government }\end{array}$ & Chong-en Bai, Yu Pan and Yijiang Wang & June 1998 \\
\hline $\begin{array}{l}\text { No. 172: Political Instability and Growth in } \\
\text { Proprietary Economies }\end{array}$ & Jody Overland and Michael Spagat & August 1998 \\
\hline $\begin{array}{l}\text { No. 171: Published in Post-Communist } \\
\text { Economies, "Framework Issues in the } \\
\text { Privatization Strategies of the Czech Republic, } \\
\text { Hungary, and Poland" Vol. 11, no. 1 March } \\
\text { 1999. }\end{array}$ & Morris Bornstein & June 1998 \\
\hline $\begin{array}{l}\text { No. 170: Published in: European Journal of } \\
\text { Political Economy "Privatization, Ownership } \\
\text { Structure and Transparency: How to Measure } \\
\text { a Real Involvement of the State” 15(4), } \\
\text { November 1999, pp. 605-18. }\end{array}$ & Frantisek Turnovec & May 1998 \\
\hline $\begin{array}{l}\text { No. } 169 \text { Published in: American Economic } \\
\text { Review, “Unemployment and the Social Safety } \\
\text { Net during Transitions to a Market Economy: } \\
\text { Evidence from Czech and Slovak Men.” Vol. } \\
\text { 88, No. 5, Dec. 1998, pp. 1117-1142. }\end{array}$ & $\begin{array}{l}\text { John C. Ham, Jan Svejnar, and Katherine } \\
\text { Terrell }\end{array}$ & December 1998 \\
\hline $\begin{array}{l}\text { No. 167: Voucher Privatization with } \\
\text { Investment Funds: An Institutional Analysis }\end{array}$ & David Ellerman & March 1998 \\
\hline $\begin{array}{l}\text { No. 166: Published in: Marketing Issues in } \\
\text { Transitional Economies, "Value Priorities } \\
\text { and Consumer Behavior in a Transitional } \\
\text { Economy: The Case of South Africa” ed. } \\
\text { Rajeev Batra. }\end{array}$ & $\begin{array}{l}\text { Steven M. Burgess and Jan-Benedict E.M. } \\
\text { Steenkamp }\end{array}$ & August 1998 \\
\hline $\begin{array}{l}\text { No. 164: Finance and Investment in } \\
\text { Transition: Czech Enterprises, 1993-1994 }\end{array}$ & Ronald Anderson and Chantal Kegels & September 1997 \\
\hline $\begin{array}{l}\text { No. 163: European Union Trade and } \\
\text { Investment Flows U-Shaping Industrial }\end{array}$ & Alexander Repkine and Patrick P. Walsh & April 1998 \\
\hline
\end{tabular}


William Davidson Institute Working Paper 339

\begin{tabular}{|c|c|c|}
\hline $\begin{array}{l}\text { Output in Central and Eastern Europe: } \\
\text { Theory and Evidence }\end{array}$ & & \\
\hline $\begin{array}{l}\text { No. 162: Skill Acquisition and Private Firm } \\
\text { Creation in Transition Economies }\end{array}$ & Zuzana Brixiova and Wenli Li & October 1999 \\
\hline No. 161: Corruption in Transition & Susanto Basu and David D. Li & May 1998 \\
\hline $\begin{array}{l}\text { No. 160a: Tenures that Shook the World: } \\
\text { Worker Turnover in Russia, Poland and } \\
\text { Britain }\end{array}$ & $\begin{array}{l}\text { Hartmut Lehmann and Jonathan } \\
\text { Wadsworth }\end{array}$ & November 1999 \\
\hline $\begin{array}{l}\text { No. 160: Tenures that Shook the World: } \\
\text { Worker Turnover in the Russian Federation } \\
\text { and Poland }\end{array}$ & $\begin{array}{l}\text { Hartmut Lehmann and Jonathan } \\
\text { Wadsworth }\end{array}$ & June 1998 \\
\hline $\begin{array}{l}\text { No. 159: Does Market Structure Matter? New } \\
\text { Evidence from Russia }\end{array}$ & Annette N. Brown and J. David Brown & June 1998 \\
\hline $\begin{array}{l}\text { No. 158: Structural Adjustment and Regional } \\
\text { Long Term Unemployment in Poland }\end{array}$ & Hartmut Lehmann and Patrick P. Walsh & June 1997 \\
\hline $\begin{array}{l}\text { No. 157: Baby Boom or Bust? Changing } \\
\text { Fertility in Post-Communist Czech Republic } \\
\text { and Slovakia }\end{array}$ & Robert S. Chase & April 1998 \\
\hline $\begin{array}{l}\text { No. } 156 \text { Published in: Leadership and } \\
\text { Organization Development Journal, } \\
\text { "Leading Radical Change in Transition } \\
\text { Economies." Vol. 19, No. 6, 1998, pp. 309- } \\
\text { 324. }\end{array}$ & Karen L. Newman & June 1998 \\
\hline $\begin{array}{l}\text { No. } 155 \text { Published in: Oxford Review of } \\
\text { Economic Policy, "From Theory into } \\
\text { Practice? Restructuring and Dynamism in } \\
\text { Transition Economies." Vol. 13, No. 2, } \\
\text { Summer 1997, pp. 77-105. }\end{array}$ & Wendy Carlin and Michael Landesmann & June 1997 \\
\hline $\begin{array}{l}\text { No. 154: The Model and the Reality: } \\
\text { Assessment of Vietnamese SOE Reform- } \\
\text { Implementation at the Firm Level }\end{array}$ & $\begin{array}{l}\text { Edmund Malesky, Vu Thanh Hung, Vu Thi } \\
\text { Dieu Anh, and Nancy K. Napier }\end{array}$ & July 1998 \\
\hline $\begin{array}{l}\text { No. } 153 \text { Published in: Journal of } \\
\text { Comparative Economics, "Causes of the Soft } \\
\text { Budget Constraint: Evidence on Three } \\
\text { Explanations." Vol. 26, No. 1, March 1998, } \\
\text { pp. 104-116. }\end{array}$ & David D. Li and Minsong Liang & March 1998 \\
\hline $\begin{array}{l}\text { No. } 152 \text { Published in: Comparative Economic } \\
\text { Studies, "Enterprise Restructuring in Russia's } \\
\text { Transition Economy: Formal and Informal } \\
\text { Mechanisms." Vol. 40, No. 2, Summer 1998, } \\
\text { pp. 5-52. }\end{array}$ & Susan J. Linz and Gary Krueger & April 1998 \\
\hline $\begin{array}{l}\text { No. 151: Labor Productivity in Transition: A } \\
\text { Regional Analysis of Russian Industry }\end{array}$ & Susan J. Linz & May 1998 \\
\hline $\begin{array}{l}\text { No. 150: Tax Avoidance and the Allocation of } \\
\text { Credit. Forthcoming in Financial Systems in } \\
\text { Transition: The Design of Financial Systems } \\
\text { in Central Europe eds. Anna Meyendorff and } \\
\text { Anjan Thakor. }\end{array}$ & Anna Meyendorff & June 1998 \\
\hline $\begin{array}{l}\text { No. 149: Commitment, Versatility and } \\
\text { Balance: Determinants of Work Time } \\
\text { Standards and Norms in a Multi-Country } \\
\text { Study of Software Engineers }\end{array}$ & Leslie Perlow and Ron Fortgang & April 1998 \\
\hline $\begin{array}{l}\text { No. 148: Changes in Poland's Transfer } \\
\text { Payments in the 1990s: the Fate of } \\
\text { Pensioners }\end{array}$ & Bozena Leven & June 1998 \\
\hline $\begin{array}{l}\text { No. 147: Environmental Protection and } \\
\text { Economic Development: The Case of the } \\
\text { Huaihe River Basin Cleanup Plan }\end{array}$ & $\begin{array}{l}\text { Robert Letovsky, Reze Ramazani, and } \\
\text { Debra Murphy }\end{array}$ & June 1998 \\
\hline
\end{tabular}




\begin{tabular}{|c|c|c|}
\hline $\begin{array}{l}\text { No. 146: Chief Executive Compensation } \\
\text { During Early Transition: Further Evidence } \\
\text { from Bulgaria }\end{array}$ & $\begin{array}{l}\text { Derek C. Jones, Takao Kato, and Jeffrey } \\
\text { Miller }\end{array}$ & June 1998 \\
\hline $\begin{array}{l}\text { No. } 145 \text { Published in: Economics of } \\
\text { Transition, “Women's Unemployment During } \\
\text { the Transition: Evidence from Czech and } \\
\text { Slovak Micro Data," Vol. 7, No. 1, May 1999, } \\
\text { pp. 47-78. }\end{array}$ & $\begin{array}{l}\text { John Ham, Jan Svejnar, and Katherine } \\
\text { Terrell }\end{array}$ & May 1998 \\
\hline No. 144: Investment and Wages in Slovenia & Janez Prasnikar & May 1998 \\
\hline $\begin{array}{l}\text { No. } 143 \text { Published in: Review of Financial } \\
\text { Studies, “Optimal Bankruptcy Laws Across } \\
\text { Different Economic Systems," 12(2), Summer } \\
\text { 1999, pgs. 347-77. }\end{array}$ & Elazar Berkovitch and Ronen Israel & March 1998 \\
\hline $\begin{array}{l}\text { No. 142: Industrial Policy and Poverty in } \\
\text { Transition Economies: Two Steps Forward or } \\
\text { One Step Back? }\end{array}$ & Susan J. Linz & March 1998 \\
\hline $\begin{array}{l}\text { No. 141: Collective Ownership and } \\
\text { Privatization of China's Village Enterprises }\end{array}$ & Suwen Pan and Albert Park & April 1998 \\
\hline $\begin{array}{l}\text { No. 140: A Comparative Look at Labor } \\
\text { Mobility in the Czech Republic: Where have } \\
\text { all the Workers Gone? }\end{array}$ & Vit Sorm and Katherine Terrell & April 1999 \\
\hline $\begin{array}{l}\text { No. 139: The Failure of the Government-Led } \\
\text { Program of Corporate Reorganization in } \\
\text { Romania }\end{array}$ & Simeon Djankov and Kosali Ilayperuma & September 1997 \\
\hline $\begin{array}{l}\text { No. 138: Ownership and Employment in } \\
\text { Russian Industry: 1992-1995 }\end{array}$ & Susan J. Linz & March 1998 \\
\hline $\begin{array}{l}\text { No. } 137 \text { Published in: Journal of Political } \\
\text { Economy, "Reform Without Losers: An } \\
\text { Interpretation of China's Dual-Track } \\
\text { Approach to Transition," Feb. 2000; Vol. 108, } \\
\text { Iss.1; pg. } 120\end{array}$ & $\begin{array}{l}\text { Lawrence J. Lau, Yingyi Qian, and Gerard } \\
\text { Roland }\end{array}$ & November 1997 \\
\hline $\begin{array}{l}\text { No. } 136 \text { Published in: European Economic } \\
\text { Review, "The Political Economy of Mass } \\
\text { Privatization and the Risk of Expropriation," } \\
44(2), \text { February 2000, pgs. 393-421 }\end{array}$ & Klaus M. Schmidt & March 1998 \\
\hline $\begin{array}{l}\text { No. 135: Radical Organizational Change: The } \\
\text { Role of Starting Conditions, Competition, and } \\
\text { Leaders }\end{array}$ & Karen L. Newman & January 1998 \\
\hline $\begin{array}{l}\text { No. 134: To Restructure or Not to } \\
\text { Restructure: Informal Activities and } \\
\text { Enterprise Behavior in Transition } \\
\text { No. 133: Management 101: Behavior of Firms } \\
\text { in Transition Economies }\end{array}$ & Clifford Gaddy and Barry W. Ickes & $\begin{array}{l}\text { May } 1998 \\
\text { March } 1998\end{array}$ \\
\hline $\begin{array}{l}\text { No. } 132 \text { Published in: Quarterly Journal of } \\
\text { Economics, “Interfirm Relationships and } \\
\text { Informal Credit in Vietnam," 114(4), Nov. } \\
\text { 1999, pgs. 1285-1320 }\end{array}$ & John McMillan and Christopher Woodruff & February 1998 \\
\hline $\begin{array}{l}\text { No. } 131 \text { Published in: Comparative Economic } \\
\text { Studies, "Will Restructuring Hungarian } \\
\text { Companies Innovate? An Investigation Based } \\
\text { on Joseph Berliner's Analysis of Innovation in } \\
\text { Soviet Industry." Vol. 40, No. 2, Summer } \\
\text { 1998, pp. 53-74. }\end{array}$ & John B. Bonin and Istvan Abel & March 1998 \\
\hline $\begin{array}{l}\text { No. 130: Published in The American } \\
\text { Economic Review, "Changing Incentives of } \\
\text { the Chinese Bureaucracy." May, 1998. }\end{array}$ & David D. Li & January 1998 \\
\hline $\begin{array}{l}\text { No. 129: Restructuring Investment in } \\
\text { Transition: A Model of the Enterprise }\end{array}$ & Richard E. Ericson & January 1998 \\
\hline
\end{tabular}




\begin{tabular}{|c|c|c|}
\hline Decision & & \\
\hline $\begin{array}{l}\text { No. } 128 \text { Published in: Comparative Economic } \\
\text { Studies, "Job Rights in Russian Firms: } \\
\text { Endangered or Extinct Institutions?" Vol. 40, } \\
\text { No. 4, Winter 1998, pp. 1-32. }\end{array}$ & Susan J. Linz & January 1998 \\
\hline $\begin{array}{l}\text { No. 127: Accounting for Growth in Post- } \\
\text { Soviet Russia }\end{array}$ & Daniel Berkowitz and David N. DeJong & January 1998 \\
\hline $\begin{array}{l}\text { No. } 126 \text { Published in: Economics of } \\
\text { Transition, "From Federalism, Chinese Style, } \\
\text { to Privatization Chinese Style," 7(1), 1999, } \\
\text { pgs. 103-31 }\end{array}$ & $\begin{array}{l}\text { Yuanzheng Cao, Yingyi Qian, and Barry R. } \\
\text { Weingast }\end{array}$ & December 1997 \\
\hline $\begin{array}{l}\text { No. 125: Market Discipline in Conglomerate } \\
\text { Banks: Is an Internal Allocation of Cost of } \\
\text { Capital Necessary as Incentive Device? } \\
\text { Forthcoming in Financial Systems in } \\
\text { Transition: The Design of Financial Systems } \\
\text { in Central Europe eds. Anna Meyendorff and } \\
\text { Anjan Thakor. }\end{array}$ & Arnoud W. A. Boot and Anjolein Schmeits & November 1997 \\
\hline $\begin{array}{l}\text { No. 124: Financial Discipline in the } \\
\text { Enterprise Sector in Transition Countries: } \\
\text { How Does China Compare? }\end{array}$ & Shumei Gao and Mark E. Schaffer & February 1998 \\
\hline $\begin{array}{l}\text { No. 123: Considerations of an Emerging } \\
\text { Marketplace: Managers' Perceptions in the } \\
\text { Southern African Economic Community }\end{array}$ & Brent Chrite and David Hudson & February 1998 \\
\hline $\begin{array}{l}\text { No. 122: A Model of the Informal Economy in } \\
\text { Transition Economies }\end{array}$ & $\begin{array}{l}\text { Simon Commander and Andrei } \\
\text { Tolstopiatenko }\end{array}$ & November 1997 \\
\hline $\begin{array}{l}\text { No. 121: Local Labour Market Dynamics in } \\
\text { the Czech and Slovak Republics }\end{array}$ & Peter Huber and Andreas Worgotter & November 1997 \\
\hline $\begin{array}{l}\text { No. 121: Local Labour Market Dynamics in } \\
\text { the Czech and Slovak Republics }\end{array}$ & Peter Huber and Andreas Worgotter & November 1997 \\
\hline $\begin{array}{l}\text { No. 119: Institutional Upheaval and Company } \\
\text { Transformation in Emerging Market } \\
\text { Economies }\end{array}$ & Karen L. Newman & March 1998 \\
\hline $\begin{array}{l}\text { No. 118: Industrial Decline and Labor } \\
\text { Reallocation in Romania }\end{array}$ & John S. Earle & October 1997 \\
\hline $\begin{array}{l}\text { No. 117: Notes for an Essay on the Soft } \\
\text { Budget Constraint }\end{array}$ & Lorand Ambrus-Lakatos & January 1997 \\
\hline $\begin{array}{l}\text { No. 116: Labor Demand During Transition in } \\
\text { Hungary }\end{array}$ & Gabor Korosi & October 1997 \\
\hline $\begin{array}{l}\text { No. 115: Enterprise Performance and } \\
\text { Managers'Profiles }\end{array}$ & Simeon Djankov and Stijn Claessens & December 1997 \\
\hline $\begin{array}{l}\text { No. } 114 \text { E Employment and Wages in } \\
\text { Enterprises under Communism and in } \\
\text { Transition: Evidence From Central Europe } \\
\text { and Russia }\end{array}$ & Swati Basu, Saul Estrin, and Jan Svejnar & April 2000 \\
\hline $\begin{array}{l}\text { No. 114: Employment and Wage Behavior of } \\
\text { Enterprises in Transitional Economies }\end{array}$ & Swati Basu, Saul Estrin, and Jan Svejnar & October 1997 \\
\hline $\begin{array}{l}\text { No. 113: Preliminary Evidence on Active } \\
\text { Labor Programs' Impact in Hungary and } \\
\text { Poland }\end{array}$ & Christopher J. O'Leary & October 1997 \\
\hline $\begin{array}{l}\text { No. 111: Unemployment Benefits and } \\
\text { Incentives in Hungary: New Evidence }\end{array}$ & Joachim Wolff & October 1997 \\
\hline $\begin{array}{l}\text { No. 110: Published in: Empirical Economics, } \\
\text { "Long-Term Unemployment, Unemployment } \\
\text { Benefits and Social Assistance: The Polish } \\
\text { Experience” Empirical-Economics; 23(1-2), } \\
\text { 1998, pages 55-85. }\end{array}$ & Marek Gora and Christoph M. Schmidt & April 1997 \\
\hline No. 109 Published in: Industrial and Labor & Robert S. Chase & October 1997 \\
\hline
\end{tabular}




\begin{tabular}{|c|c|c|}
\hline $\begin{array}{l}\text { Relations Review, "Markets for Communist } \\
\text { Human Capital: Returns to Education and } \\
\text { Experience in Post-Communist Czech } \\
\text { Republic and Slovakia." Vol. 51, No. 3, April } \\
\text { 1998, pp. 401-423. }\end{array}$ & & \\
\hline $\begin{array}{l}\text { No. 107: The Worker-Firm Matching in the } \\
\text { Transition: (Why) Are the Czechs More } \\
\text { Successful Than Others? }\end{array}$ & $\begin{array}{l}\text { Daniel Münich, Jan Svejnar, and } \\
\text { Katherine Terrell }\end{array}$ & October 1997 \\
\hline $\begin{array}{l}\text { No. } 106 \text { Published in: Journal of } \\
\text { Comparative Economics, "Job Creation, Job } \\
\text { Destruction and Growth of Newly Established, } \\
\text { Privatized and State-Owned Enterprises in } \\
\text { Transition Economies: Survey Evidence from } \\
\text { Bulgaria, Hungary, and Romania," Vol. 26, } \\
\text { No.3, September 1998, pp. 429-445. }\end{array}$ & Valentijn Bilsen and Jozef Konings & September 1998 \\
\hline $\begin{array}{l}\text { No. 105: Getting Behind the East-West } \\
\text { [German] Wage Differential: Theory and } \\
\text { Evidence }\end{array}$ & Michael Burda and Christoph Schmidt & May 1997 \\
\hline $\begin{array}{l}\text { No. 104: The Birth of the "Wage Curve" in } \\
\text { Hungary, 1989-95 }\end{array}$ & Gabor Kertesi and Janos Kollo & October 1997 \\
\hline $\begin{array}{l}\text { No. 103: Published in: Journal of } \\
\text { Comparative Economics, "Grime and } \\
\text { Punishment: Job Insecurity and Wage Arrears } \\
\text { in the Russian Federation" 27, 595-617 } \\
\text { (1999). }\end{array}$ & $\begin{array}{l}\text { Hartmut Lehmann, Jonathan Wadsworth, } \\
\text { and Alessandro Acquisti }\end{array}$ & October 1997 \\
\hline No. 102: Social Networks in Transition & $\begin{array}{l}\text { Lorena Barberia, Simon Johnson, and } \\
\text { Daniel Kaufmann }\end{array}$ & October 1997 \\
\hline $\begin{array}{l}\text { No. 101: Depreciation and Russian Corporate } \\
\text { Finance: A Pragmatic Approach to Surviving } \\
\text { the Transition }\end{array}$ & Susan J. Linz & November 1997 \\
\hline No. 100: Romanian Financial System Reform & Anna Meyendorff and Anjan V. Thakor & November 1997 \\
\hline $\begin{array}{l}\text { No. 99: Proceedings of the Conference on } \\
\text { Strategic Alliances in Transitional Economies, } \\
\text { held May 20, } 1997 \text { at the Davidson Institute }\end{array}$ & Edited by Cynthia Koch & May 1997 \\
\hline $\begin{array}{l}\text { No. 98: Institutions, Strain and the } \\
\text { Underground Economy }\end{array}$ & Daniel Daianu and Lucian Albu & November 1997 \\
\hline $\begin{array}{l}\text { No. 97: Structure and Strain in Explaining } \\
\text { Inter-Enterprise Arrears }\end{array}$ & Daniel Daianu & November 1997 \\
\hline $\begin{array}{l}\text { No. 96: Resource Misallocation and Strain: } \\
\text { Explaining Shocks in Post-Command } \\
\text { Economies }\end{array}$ & Daniel Daianu & November 1997 \\
\hline $\begin{array}{l}\text { No. 95: Published in: Finance-a-Uver, } \\
\text { "Czech Money Market: Emerging Links } \\
\text { Among Interest Rates." 48(2) } 1998 \text { pp. 99- } \\
\text { 109. }\end{array}$ & Jan Hanousek and Evzen Kocenda & November 1997 \\
\hline $\begin{array}{l}\text { No. 94: Pre-Reform Industry and the } \\
\text { State Monopsony in China }\end{array}$ & Xiao-Yuan Dong and Louis Putterman & October 1997 \\
\hline $\begin{array}{l}\text { No. 93: China's State-Owned Enterprises } \\
\text { In the First Reform Decade: } \\
\text { An Analysis of a Declining Monopsony }\end{array}$ & Xiao-Yuan Dong and Louis Putterman & October 1997 \\
\hline $\begin{array}{l}\text { No. 92: Expatriate Management in the Czech } \\
\text { Republic }\end{array}$ & Richard B. Peterson & September 1997 \\
\hline $\begin{array}{l}\text { No. 91: China and the Idea of Economic } \\
\text { Reform }\end{array}$ & Thomas G. Rawski & April 1997 \\
\hline $\begin{array}{l}\text { No. } 90 \text { Published in: China Economic } \\
\text { Review, "China's State Enterprise Reform: An } \\
\text { Overseas Perspective." Vol. 8, Spring 1997, } \\
\text { pp. 89-98. }\end{array}$ & Thomas G. Rawski & July 1997 \\
\hline
\end{tabular}




\begin{tabular}{|c|c|c|}
\hline $\begin{array}{l}\text { No. 89: The Economic Determinants of } \\
\text { Internal Migration Flows in Russia During } \\
\text { Transition }\end{array}$ & Annette N. Brown & July 1997 \\
\hline $\begin{array}{l}\text { No. 88: Gender Wage Gaps in China's Labor } \\
\text { Market: Size, Structure, Trends }\end{array}$ & $\begin{array}{l}\text { Margaret Maurer-Fazio, Thomas G. } \\
\text { Rawski, and Wei Zhang }\end{array}$ & July 1997 \\
\hline $\begin{array}{l}\text { No. 87: Privatisation in Central and Eastern } \\
\text { Europe }\end{array}$ & Saul Estrin & June 1997 \\
\hline $\begin{array}{l}\text { No. 86: Published in : Economics of } \\
\text { Transition, "The Effect of Privatization on } \\
\text { Wealth Distribution in Russia." v. 7, no. 2, } \\
\text { 1999, pp. 449-65 }\end{array}$ & Michael Alexeev & February 1998 \\
\hline $\begin{array}{l}\text { No. 85: Was Privatization in Eastern Germany } \\
\text { a Special Case? Some Lessons from the } \\
\text { Treuhand }\end{array}$ & Uwe Siegmund & September 1997 \\
\hline No. 84: Start-ups and Transition & Daniel M. Berkowitz and David J. Cooper & September 1997 \\
\hline $\begin{array}{l}\text { No. 83: Which Enterprises (Believe They) } \\
\text { Have Soft Budgets after Mass Privatization? } \\
\text { Evidence from Mongolia }\end{array}$ & $\begin{array}{l}\text { James Anderson, Georges Korsun, and } \\
\text { Peter Murrell }\end{array}$ & October 1997 \\
\hline $\begin{array}{l}\text { No. 82: Published in: European Economic } \\
\text { Review, "Unemployment Dynamics and the } \\
\text { Restructuring of the Slovak Unemployment } \\
\text { Benefit System." April, 1997. }\end{array}$ & Martina Lubyova and Jan C. van Ours & June 1997 \\
\hline $\begin{array}{l}\text { No. 81: Determinants of Unemployment } \\
\text { Duration in Russia }\end{array}$ & Mark C. Foley & August 1997 \\
\hline $\begin{array}{l}\text { No. 80: The Many Faces of Information } \\
\text { Disclosure }\end{array}$ & Arnoud W.A. Boot and Anjan V. Thakor & October 1997 \\
\hline $\begin{array}{l}\text { No. 79: Published in: Journal of Finance, } \\
\text { "Foreign Speculators and Emerging Equity } \\
\text { Markets."v.22, iss. 2, 2000, pp. 565-613 }\end{array}$ & Geert Bekaert and Campbell R. Harvey & August 1997 \\
\hline $\begin{array}{l}\text { No. 78: The Relationship Between Economic } \\
\text { Factors and Equity Markets in Central Europe }\end{array}$ & Jan Hanousek and Randall K. Filer & June 1997 \\
\hline $\begin{array}{l}\text { No. } 77 \text { Published in: Economics of } \\
\text { Transition, “A Gini Decomposition Analysis } \\
\text { of Inequality in the Czech and Slovak } \\
\text { Republics During the Transition," Vol. 6, } \\
\text { No.1, May 1998, pp. 23-46. }\end{array}$ & Thesia I. Garner and Katherine Terrell & May 1998 \\
\hline $\begin{array}{l}\text { No. 76: China's Emerging Market for } \\
\text { Property Rights: Theoretical and Empirical } \\
\text { Perspectives }\end{array}$ & Gary H. Jefferson and Thomas G. Rawski & June 1997 \\
\hline $\begin{array}{l}\text { No. } 75 b: \text { Test of Permanent Income } \\
\text { Hypothesis on Czech Voucher Privatization }\end{array}$ & Jan Hanousek and Zdenek Tima & October 1997 \\
\hline $\begin{array}{l}\text { No. 74: Determinants of Performance of } \\
\text { Manufacturing Firms in Seven European } \\
\text { Transition Economies }\end{array}$ & $\begin{array}{l}\text { Stijn Claessens, Simeon Djankov, and } \\
\text { Gerhard Pohl }\end{array}$ & February 1997 \\
\hline $\begin{array}{l}\text { No. } 73 \text { Published in: Economics of } \\
\text { Transition, "The Restructuring of Large } \\
\text { Firms in Slovak Republic." Vol. 6, No. 1, May } \\
\text { 1998, pp. 67-85 }\end{array}$ & Simeon Djankov and Gerhard Pohl & May 1998 \\
\hline $\begin{array}{l}\text { No. 72: Law, Relationships, and Private } \\
\text { Enforcement: Transactional Strategies of } \\
\text { Russian Enterprises }\end{array}$ & $\begin{array}{l}\text { Kathryn Hendley, Peter Murrell, and } \\
\text { Randi Ryterman }\end{array}$ & November 1998 \\
\hline $\begin{array}{l}\text { No. 71: Giving Credit Where Credit Is Due: } \\
\text { The Changing Role of Rural Financial } \\
\text { Institutions in China }\end{array}$ & Albert Park, Loren Brandt, and John Giles & March 1997 \\
\hline $\begin{array}{l}\text { No. 70: Privatization Versus Competition: } \\
\text { Changing Enterprise Behavior in Russia }\end{array}$ & John S. Earle and Saul Estrin & Spring 1997 \\
\hline $\begin{array}{l}\text { No. 69: Russian Managers under Storm: } \\
\text { Explicit Reality and Implicit Leadership }\end{array}$ & Igor Gurkov & October 1998 \\
\hline
\end{tabular}




\begin{tabular}{|c|c|c|}
\hline Theories (A Pilot Exploration) & & \\
\hline $\begin{array}{l}\text { No. 68: The Political Economy of Central- } \\
\text { Local Relations in China: Inflation and } \\
\text { Investment Controls During the Reform Era }\end{array}$ & Yasheng Huang & Spring 1997 \\
\hline $\begin{array}{l}\text { No. 67: Between Two Coordination Failures: } \\
\text { Automotive Industrial Policy in China with a } \\
\text { Comparison to Korea }\end{array}$ & Yasheng Huang & Spring 1997 \\
\hline $\begin{array}{l}\text { No. } 66 \text { Published in: Post-Soviet Geography } \\
\text { and Economics, "Red Executives in Russia's } \\
\text { Transition Economy." Vol. 27, No. 10, } \\
\text { November 1996, pp. 633-651. }\end{array}$ & Susan J. Linz & January 1997 \\
\hline $\begin{array}{l}\text { No. } 65 \text { Published in: Industrial and } \\
\text { Corporate Change, "On the Sequencing of } \\
\text { Privatization in Transition Economies." Vol. } \\
7, \text { No. 1, 1998. }\end{array}$ & Gautam Ahuja and Sumit K. Majumdar & April 1997 \\
\hline $\begin{array}{l}\text { No. 64: Published in: Journal of Law and } \\
\text { Economics, "Foreign Ownership and } \\
\text { Profitability: Property Rights, Control and the } \\
\text { Performance of Firms in Indian Industry" } \\
\text { 42(1), April 1999, pp. 209-38. }\end{array}$ & $\begin{array}{l}\text { Pradeep K. Chhibber and Sumit K. } \\
\text { Majumdar }\end{array}$ & April 1997 \\
\hline $\begin{array}{l}\text { No. 63: How Taxing Is Corruption on } \\
\text { International Investors? }\end{array}$ & Shang-Jin Wei & February 1997 \\
\hline $\begin{array}{l}\text { No. 62: What Can We Learn from the } \\
\text { Experience of Transitional Economies with } \\
\text { Labour Market Policies? }\end{array}$ & Tito Boeri & 1997 \\
\hline $\begin{array}{l}\text { No. 61: Published in: Accounting } \\
\text { Organizations and Society, "Economic } \\
\text { Transition, Strategy and the Evolution of } \\
\text { Management Accounting Practices: The Case } \\
\text { of India" 24(5,6), Jul/Aug 1999, pp. 379-412. }\end{array}$ & $\begin{array}{l}\text { Shannon W. Anderson and William } N . \\
\text { Lanen }\end{array}$ & April 1997 \\
\hline $\begin{array}{l}\text { No. 60a: Enterprise Investment During the } \\
\text { Transition: Evidence from Czech Panel Data }\end{array}$ & Lubomír Lizal and Jan Svejnar & December 1997 \\
\hline $\begin{array}{l}\text { No. 59: Published in: Journal of Law, } \\
\text { Economics, and Organization, "Institutional } \\
\text { Environment, Community Government, and } \\
\text { Corporate Governance: Understanding } \\
\text { China's Township-Village Enterprises." } \\
\text { 14(1), April 1998, pages 1-23 }\end{array}$ & Jiahua Che and Yingyi Qian & April 1997 \\
\hline $\begin{array}{l}\text { No. 58: From the Grabbing Hand to the } \\
\text { Helping Hand }\end{array}$ & Jiahua Che & June 2000 \\
\hline $\begin{array}{l}\text { No. 57: Published in: Brookings Papers on } \\
\text { Economic Activity, “The Unofficial Economy } \\
\text { in Transition." 1: 1998. }\end{array}$ & $\begin{array}{l}\text { Simon Johnson, Daniel Kaufmann, and } \\
\text { Andrei Schleifer }\end{array}$ & June 1997 \\
\hline $\begin{array}{l}\text { No. 56: Taxes and Government Incentives: } \\
\text { Eastern Europe vs. China }\end{array}$ & Roger H. Gordon and David D. Li & April 1997 \\
\hline No. 55: Corruption and Reform & Susanto Basu and David Li & June 1996 \\
\hline $\begin{array}{l}\text { No. 54: Decentralization and the } \\
\text { Macroeconomic Consequences of } \\
\text { Commitment to State-Owned Firms }\end{array}$ & Loren Brandt and Xiaodong Zhu & June 1997 \\
\hline $\begin{array}{l}\text { No. 53: Published in: The International } \\
\text { Journal of Industrial Organization, } \\
\text { "Competitive Shocks and Industrial Structure: } \\
\text { The Case of Polish Manufacturing.” August, } \\
\text { 1999. . }\end{array}$ & Pankaj Ghemawat and Robert E. Kennedy & May 1997 \\
\hline $\begin{array}{l}\text { No. 52: Published in: The Quarterly Journal } \\
\text { of Economics, "Insecure Property Rights and } \\
\text { Government Ownership of Firms." May, } \\
\text { 1998. }\end{array}$ & Jiahua Che and Yingyi Qian & May 1997 \\
\hline
\end{tabular}




\begin{tabular}{|c|c|c|}
\hline $\begin{array}{l}\text { No. 51: Incentives, Scale Economies, and } \\
\text { Organizational Form }\end{array}$ & $\begin{array}{l}\text { Eric Maskin, Yingyi Qian, and Chenggang } \\
X u\end{array}$ & May 1997 \\
\hline $\begin{array}{l}\text { No. 50: Published in: Post-Soviet-Affairs, } \\
\text { "End of the Tunnel? The Effects of Financial } \\
\text { Stabilization in Russia" April-June 1997, } \\
\text { pages 105-33 }\end{array}$ & $\begin{array}{l}\text { Barry W. Ickes, Peter Murrell, and Randi } \\
\text { Ryterman }\end{array}$ & March 1997 \\
\hline $\begin{array}{l}\text { No. 49: The Evolution of Bank Credit Quality } \\
\text { in Transition: Theory and Evidence from } \\
\text { Romania }\end{array}$ & Enrico C. Perotti and Octavian Carare & October 1996 \\
\hline $\begin{array}{l}\text { No. 48: Where Do the Leaders Trade? } \\
\text { Information Revelation and Interactions } \\
\text { Between the Segments of Czech Capital } \\
\text { Markets }\end{array}$ & Jan Hanousek and Libor Nemecek & May 1997 \\
\hline $\begin{array}{l}\text { No. 47: Firms' Heterogeneity in Transition: } \\
\text { Evidence from a Polish Panel Data Set }\end{array}$ & Irena Grosfeld and Jean-François Nivet & May 1997 \\
\hline $\begin{array}{l}\text { No. 46: Strategic Creditor Passivity, } \\
\text { Regulation, and Bank Bailouts }\end{array}$ & Janet Mitchell & May 1997 \\
\hline $\begin{array}{l}\text { No. 45a: Published in: Journal of Public } \\
\text { Economics, "Tax Rights in Transition } \\
\text { Economies: A Tragedy of the Commons." 76, } \\
\text { 2000, pp. 369-397 }\end{array}$ & Daniel M. Berkowitz and Wei Li & September 1997 \\
\hline $\begin{array}{l}\text { No. 44a: The Information Content of Stock } \\
\text { Markets: Why do Emerging Markets have } \\
\text { Synchronous Stock Price Movements? } \\
\text { (forthcoming in the Journal of Financial } \\
\text { Economics). }\end{array}$ & $\begin{array}{l}\text { Randall Morck, Bernard Yeung, and } \\
\text { Wayne Yu }\end{array}$ & February 1999 \\
\hline $\begin{array}{l}\text { No. 43: Agency in Project Screening and } \\
\text { Termination Decisions: Why Is Good Money } \\
\text { Thrown After Bad? }\end{array}$ & Chong-en Bai and Yijiang Wang & May 1997 \\
\hline $\begin{array}{l}\text { No. 42: Published in: Economics of } \\
\text { Transition, "Channels of Redistribution: } \\
\text { Inequality and Poverty in the Russian } \\
\text { Transition." Vol. } 7 \text { (2) } 1999 .\end{array}$ & $\begin{array}{l}\text { Simon Commander, Andrei } \\
\text { Tolstopiatenko, and Ruslan Yemtsov }\end{array}$ & May 1997 \\
\hline $\begin{array}{l}\text { No. 41: Published in: Economics of } \\
\text { Transition, "Labour Market Characteristics } \\
\text { and Profitability: Econometric Analysis of } \\
\text { Hungarian Exporting Firms, 1986-1995" } \\
\text { 6(1), May 1998, pages 145-62 }\end{array}$ & László Halpern and Gabor Korosi & May 1997 \\
\hline $\begin{array}{l}\text { No. 40: Published in: the Harvard Law } \\
\text { Review, "The Tragedy of the Anticommons: } \\
\text { Property in the Transition from Marx to } \\
\text { Markets." January 1998. }\end{array}$ & Michael Heller & February 1997 \\
\hline $\begin{array}{l}\text { No. 39: Privatization and Managerial } \\
\text { Efficiency }\end{array}$ & Olivier Debande and Guido Friebel & May 1997 \\
\hline $\begin{array}{l}\text { No. } 38 \text { Published in: The Quarterly Journal } \\
\text { of Economics, “Disorganization.” Vol. 112, } \\
\text { No. 4, November 1997, pp. 1091-1126. }\end{array}$ & Olivier Blanchard and Michael Kremer & January 1997 \\
\hline $\begin{array}{l}\text { No. 37: Published in: Economics of } \\
\text { Transition, "Transition and the Output Fall." } \\
\text { 7(1), 1999, pages 1-28. }\end{array}$ & Gérard Roland and Thierry Verdier & March 1997 \\
\hline $\begin{array}{l}\text { No. 36: Restructuring an Industry During } \\
\text { Transition: A Two-Period Model }\end{array}$ & Richard Ericson & September 1996 \\
\hline $\begin{array}{l}\text { No. 34: The East-West Joint Venture: BC } \\
\text { Torsion Case Study }\end{array}$ & Sonia Ferencikova and Vern Terpstra & December 1998 \\
\hline $\begin{array}{l}\text { No. } 33 \text { Published in: Journal of Comparative } \\
\text { Economics, “Quantifying Price Liberalization } \\
\text { in Russia." Vol. 26, No. 4, December 1998, } \\
\text { pp. } 735-737 .\end{array}$ & $\begin{array}{l}\text { Daniel Berkowitz, David DeJong, and } \\
\text { Steven Husted }\end{array}$ & December 1998 \\
\hline
\end{tabular}




\begin{tabular}{|c|c|c|}
\hline $\begin{array}{l}\text { No. 32: What Can North Korea Learn from } \\
\text { China's Market Reforms? }\end{array}$ & John McMillan & September 1996 \\
\hline $\begin{array}{l}\text { No. 31: Published in : China-Economic- } \\
\text { Review, “Towards a Model of China as a } \\
\text { Partially Reformed Developing Economy } \\
\text { Under a Semifederalist Government.", 9(1), } \\
\text { Spring 1998, pages 1-23. }\end{array}$ & Yijiang Wang and Chun Chang & March 1997 \\
\hline $\begin{array}{l}\text { No. 30: Convergence in Output in Transition } \\
\text { Economies: Central and Eastern Europe, } \\
\text { 1970-1995 }\end{array}$ & Saul Estrin and Giovanni Urga & February 1997 \\
\hline $\begin{array}{l}\text { No. 29: Published in: Economics of } \\
\text { Transition, "Altered Band and Exchange } \\
\text { Volatility." Volume 6, no. 1, 1998, 173-181. }\end{array}$ & Evzen Kocenda & March 1997 \\
\hline $\begin{array}{l}\text { No. 28: Published in: Quarterly Journal of } \\
\text { Economics, "Public Versus Private } \\
\text { Ownership of Firms: Evidence from Rural } \\
\text { China." Volume 113, no. 3, August 1998, 773- } \\
808 .\end{array}$ & Hehui Jin and Yingyi Qian & January 1997 \\
\hline $\begin{array}{l}\text { No. 27: East-West Joint Ventures in a } \\
\text { Transitional Economy: The Case of Slovakia }\end{array}$ & Sonia Ferencikova & March 1997 \\
\hline $\begin{array}{l}\text { No. 26: Published in Economic Analysis } \\
\text { "Behavior of a Slovenian Firm in Transition" } \\
\text { Vol. 1, no. 1, 1998, 57-73. }\end{array}$ & Janez Prasnikar & February 1997 \\
\hline $\begin{array}{l}\text { No. 25: Cultural Encounters and Claims to } \\
\text { Expertise in Postcommunist Capitalism }\end{array}$ & Michael D. Kennedy & February 1997 \\
\hline $\begin{array}{l}\text { No. 24: ZVU a.s.: Investment Funds on the } \\
\text { Board of Directors of an Engineering Giant }\end{array}$ & Tory Wolff & August 1995 \\
\hline $\begin{array}{l}\text { No. 23: The Role of Investment Funds in the } \\
\text { Czech Republic (joint publication with Czech } \\
\text { Management Center) }\end{array}$ & Dusan Triska & June 1996 \\
\hline $\begin{array}{l}\text { No. 22: Czech Investment Fund Industry: } \\
\text { Development and Behaviour (joint publication } \\
\text { with Czech Management Center) }\end{array}$ & Richard Podpiera & May 1996 \\
\hline $\begin{array}{l}\text { No. 21: Restructuring of Czech Firms: An } \\
\text { Example of Gama, a.s. (joint publication with } \\
\text { Czech Management Center) }\end{array}$ & Antonin Bulin & June 1996 \\
\hline $\begin{array}{l}\text { No. 20: YSE Funds: A Story of Czech } \\
\text { Investment Funds (joint publication with } \\
\text { Czech Management Center) }\end{array}$ & Michal Otradovec & November 1995 \\
\hline $\begin{array}{l}\text { No. 19: Prvni Investicni a.s., The First } \\
\text { Investment Corporation (joint publication } \\
\text { with Czech Management Center) }\end{array}$ & Jaroslav Jirasek & August 1995 \\
\hline $\begin{array}{l}\text { No. 18: PPF a.s., The First Private Investment } \\
\text { Fund (joint publication with Czech } \\
\text { Management Center) }\end{array}$ & Michal Otradovec & November 1995 \\
\hline $\begin{array}{l}\text { No. } 17 \text { Published in: Post-Soviet Geography } \\
\text { and Economics, "Russia's Managers in } \\
\text { Transition: Pilferers or Paladins?" Vol. 37, } \\
\text { o.7 (September 1996), pp. 397-426. }\end{array}$ & Susan J. Linz and Gary Krueger & November 1996 \\
\hline $\begin{array}{l}\text { No. 16: Banks in Transition-Investment } \\
\text { Opportunities in Central Europe and Russia } \\
\text { Edited Transcript from } 31 \text { May } 1996 \\
\text { Conference in New York City }\end{array}$ & $\begin{array}{l}\text { With commentary and edited by Anna } \\
\text { Meyendorff }\end{array}$ & January 1997 \\
\hline $\begin{array}{l}\text { No. 15: Marketing in Transitional Economies: } \\
\text { Edited Transcript \& Papers from } 1 \text { April } 1996 \\
\text { Conference in Ann Arbor, Michigan }\end{array}$ & Compiled by The Davidson Institute & December 1996 \\
\hline $\begin{array}{l}\text { No. 14: Pensions in the Former Soviet Bloc: } \\
\text { Problems and Solutions. Published by }\end{array}$ & Jan Svejnar & November 1996 \\
\hline
\end{tabular}




\begin{tabular}{|c|c|c|}
\hline $\begin{array}{l}\text { Council on Foreign Relations. "The Coming } \\
\text { Global Pension Crisis" New York, } 1997\end{array}$ & & \\
\hline $\begin{array}{l}\text { No. 13: Enterprise Restructuring and } \\
\text { Performance in the Transition. Forthcoming } \\
\text { in Financial Systems in Transition: The } \\
\text { Design of Financial Systems in Central } \\
\text { Europe eds. Anna Meyendorff and Anjan } \\
\text { Thakor. }\end{array}$ & $\begin{array}{l}\text { Lubomir Lizal, Miroslav Singer, and Jan } \\
\text { Svejnar }\end{array}$ & December 1996 \\
\hline $\begin{array}{l}\text { No. } 12 \text { Published in: Journal of International } \\
\text { Marketing, "Executive Insights: Marketing } \\
\text { Issues and Challenges in Transitional } \\
\text { Economies." Vol. 5, No. 4, 1997, pp. 95-114. } \\
\text { Also published in: Marketing Issues in } \\
\text { Transitional Economies ed. Rajeev Batra. }\end{array}$ & Rajeev Batra & April 1997 \\
\hline $\begin{array}{l}\text { No. 11: Worker Trust and System } \\
\text { Vulnerability in the Transition from Socialism } \\
\text { to Capitalism }\end{array}$ & Andrew Schotter & August 1996 \\
\hline $\begin{array}{l}\text { No. } 10 \text { Published in: Comparative Economic } \\
\text { Studies, "Russian Firms in Transition: } \\
\text { Champions, Challengers, and Chaff." Vol. } \\
\text { 39, No.2, Summer 1997, pp. 1-36. }\end{array}$ & Susan J. Linz & July 1996 \\
\hline $\begin{array}{l}\text { No. 9: Corporate Debt Crisis and Bankruptcy } \\
\text { Law During the Transition: The Case of China }\end{array}$ & David D. Li and Shan Li & December 1995 \\
\hline $\begin{array}{l}\text { No. } 8 \text { Published in: Journal of Comparative } \\
\text { Economics, "A Theory of Ambiguous } \\
\text { Property Rights in Transition Economies: The } \\
\text { Case of the Chinese Non-State Sector." Vol. } \\
\text { 23, No. 1, August 1996, pp. 1-19. }\end{array}$ & David D. Li & June 1996 \\
\hline $\begin{array}{l}\text { No. 7: The Foreign Economic Contract Law of } \\
\text { China: Cases and Analysis }\end{array}$ & Dong-lai Li & June 1993 \\
\hline $\begin{array}{l}\text { No. 3: Bank Privatization in Hungary and the } \\
\text { Magyar Kulkereskedelmi Bank Transaction }\end{array}$ & Roger Kormendi and Karen Schnatterly & May 1996 \\
\hline $\begin{array}{l}\text { Replacing Nos. 1-2 \& 4-6: Journal of } \\
\text { Comparative Economics Symposium on } \\
\text { "Bank Privatization in Central Europe and } \\
\text { Russia." Vol. 25, No. 1, August } 1997 .\end{array}$ & $\begin{array}{l}\text { No. } 1 \text { "Bank Privatization in Transitional } \\
\text { Economies" by Roger Kormendi and } \\
\text { Edward Snyder. No. } 2 \text { "Transactional } \\
\text { Structures of Bank Privatizations in } \\
\text { Central Europe and Russia” by Anna } \\
\text { Meyendorff and Edward A. Snyder. No. } 4 \\
\text { "Bank Privatization in Poland: The Case } \\
\text { of Bank Slaski” by Jeffery Abarbaness and } \\
\text { John Bonin. No. } 5 \text { "Bank Privatization in } \\
\text { Post-Communist Russia: The Case of } \\
\text { Zhilsotsbank" by Jeffery Abarbanell and } \\
\text { Anna Meyendorff and No. } 6 \text { "”'The Czech } \\
\text { Republic's Commercial Bank: Komercni } \\
\text { Banka" by Edward A. Snyder and Roger } \\
\text { C. Kormendi. }\end{array}$ & August 1997 \\
\hline
\end{tabular}

